\title{
Solanaceae na Serra Negra, Rio Preto, Minas Gerais ${ }^{1}$
}

\author{
Solanaceae in the Serra Negra, Rio Preto, Minas Gerais
}

\author{
Eveline Aparecida Feliciano ${ }^{2}$ \& Fátima Regina Gonçalves Salimena ${ }^{2,3}$
}

\begin{abstract}
Resumo
Apresenta-se o estudo taxonômico da família Solanaceae A. Juss na Serra Negra, município de Rio Preto, Minas Gerais. A família está representada na área por oito gêneros e 26 espécies. As espécies encontradas são: Athenaea picta, Aureliana fasciculata, Brugmansia suaveolens, Cestrum bracteatum, Dyssochroma viridiflorum, Nicotiana tabacum, Physalis pubescens, Solanum bullatum, S. capsicoides, S. cinnamomeum, S. decorum, S. leptostachys, S. leucodendron, S. luridifuscescens, S. lycocarpum, S. melissarum, S. palinacanthum, $S$. piluliferum, $S$. pseudoquina, $S$. schizandrum, S. sellowianum, S. sisymbriifolium, $S$. subumbellatum, S. swartzianum, S. vaillantii e $S$. velleum. Solanum é o gênero mais representativo com 19 espécies. São apresentadas chave de identificação, descrições, ilustrações, comentários taxonômicos, ecológicos e distribuição geográfica para as espécies.
\end{abstract}

Palavras-chave: Mata Atlântica, Serra da Mantiqueira, Solanum, taxonomia.

\begin{abstract}
The taxonomic study of the family Solanaceae A. Juss is represented in Serra Negra, Rio Preto municipality, Minas Gerais state is presented. In this area the family is represented by eight genera and 26 species. The species are: Athenaea picta, Aureliana fasciculata, Brugmansia suaveolens, Cestrum bracteatum, Dyssochroma viridiflorum, Nicotiana tabacum, Physalis pubescens, Solanum bullatum, S. capsicoides, S. cinnamomeum, S. decorum, S. leptostachys, S. leucodendron, S. luridifuscescens, S. lycocarpum, S. melissarum, S. palinacanthum, S. piluliferum, S. pseudoquina, S. schizandrum, S. sellowianum, S. sisymbriifolium, $S$. subumbellatum, S. swartzianum, S. vaillantii e S. velleum. Solanum is the most representative genus with 19 species. A key for identification, as well as, descriptions, illustrations, and comments about of the species taxonomy, ecology and geographic distribution is presented.
\end{abstract}

Key words: Atlantic Forest, Mantiqueira Range, Solanum, taxonomy.

\section{Introdução}

A família Solanaceae A. Juss. é uma das maiores entre as angiospermas eudicotiledôneas, reunindo 96 gêneros e aproximadamente 2300 espécies, com o maior centro de diversidade na América do Sul (D’Arcy 1991).

No Brasil ocorrem 31 gêneros e cerca de 500 espécies nativas (Hunziker 2001), sendo 28 gêneros e cerca de 450 espécies encontrados na Região Sul (Stehmann \& Mentz 2006) e 16 gêneros e 313 espécies, na Região Sudeste (Carvalho et al. 1996).

A Serra da Mantiqueira é uma das maiores e a mais importante cadeia montanhosa do sudeste brasileiro. Abrangendo parte dos estados de São Paulo, Rio de Janeiro e Minas Gerais, abriga $20 \%$ dos remanescentes da Mata Atlântica mineira (Costa \& Herrmann 2006). No Complexo da Mantiqueira, a Serra Negra é atualmente considerada prioritária para a conservação da biodiversidade de Minas Gerais, devido à elevada riqueza e grau de endemismo de espécies da sua fauna e flora (Drummond et al. 2005). Estudos florísticos recentes na área comprovaram uma elevada diversidade vegetal, com a amostragem de 157 espécies de plantas vasculares em apenas um de seus ambientes, a mata de grota (Menini Neto et al. 2009).

Visando preencher uma lacuna no conhecimento de Solanaceae na Serra da Mantiqueira, o presente trabalho teve como

\footnotetext{
${ }^{1}$ Universidade Federal de Juiz de Fora, Pós-graduação em Ecologia, Parte de Dissertação de Mestrado.

${ }^{2}$ Universidade Federal de Juiz de Fora, Depto. Botânica, Campus Universitário, R. José Lourenço Kelmer s.n., 33036-900, Juiz de Fora, MG

${ }^{3}$ Autora para correspondência: fatima.salimena@ufj.edu.br
} 
objetivo apresentar o estudo taxonômico da família na região da Serra Negra. São fornecidos uma chave de identificação, descrições, ilustrações, comentários sobre a taxonomia, ecologia e dados sobre a distribuição geográfica das espécies encontradas.

\section{Material e Métodos}

A Serra Negra está localizada no sul da Zona da Mata de Minas Gerais, nas coordenadas aproximadas de $21^{\circ} 58^{\prime} 24^{\prime}$ 'S e $43^{\circ} 53^{\prime} 15^{\prime}$ 'W, a cerca de $25 \mathrm{~km}$ do Parque Estadual do Ibitipoca, no município de Lima Duarte. Apresenta altitudes variando entre 960-1750 m e clima tropical de altitude mesotérmico, com temperaturas amenas e a precipitação média anual de $1.886 \mathrm{~mm}$ (EMATER 2003).

A Serra Negra está inserida no domínio atlântico, e sua vegetação é composta por florestas ombrófilas densas e campos rupestres. As florestas ombrófilas estão subdivididas nesta área em três formações florestais (Oliveira-Filho 2006; Valente 2007): floresta ombrófila densa aluvial, a cerca de $900 \mathrm{~m}$ de altitude em áreas periodicamente inundavéis; floresta ombrófila densa baixomontana, entre 900 a $1.100 \mathrm{~m}$ de altitude, e floresta ombrófila densa alto-montana acima de $1.100 \mathrm{~m}$ de altitude (matas nebulares)

Foram analisados materiais depositados no Herbário Leopoldo Krieger (CESJ) da Universidade Federal de Juiz de Fora, obtidos a partir de estudos florísticos iniciados em 2003 na Serra Negra. As descrições morfológicas das espécies foram realizadas com base no material coletado no projeto, seguindo a terminologia proposta por Harris \& Harris (2003) e Radford et al. (1974) para as estruturas vegetativas e florais, e a terminologia de Roe (1971) para os tricomas.
Para a complementação das descrições e a análise de padrões morfológicos dos táxons estudados foram analisadas as coleções dos herbários BHCB, MBML, R, RB, SP, SPF e VIC.

\section{Resultados e Discussão Tratamento Taxonômico Solanaceae A. Juss.}

Ervas, arbustos, árvores, escandentes ou hemiepífitas, glabros ou recobertos por diversos tipos de tricomas, espinhos ou acúleos. Folhas pecioladas ou subsésseis, alternas, isoladas ou geminadas; lâminas inteiras, lobadas a pinatissectas ou às vezes dimorfas. Inflorescências axilares, terminais, ou opostas às folhas, fasciculadas, racemosas, corimbosas ou paniculiformes, raro bracteoladas, ou flores solitárias. Flores alvas, creme, lilases, róseas, roxas e azuis, monoclinas, diclamídeas, heteroclamídeas, actinomorfas, raro levemente zigomorfas, prefloração valvar, valvarplicada ou imbricada; corola pentâmera, rotácea, campanulada infundibuliforme, hipocrateriforme ou tubulosas. Androceu pentâmero ou tetrâmero, isodínamo ou didínamo, estames pentâmeros, epipétalos, filetes retos, reflexos ou geniculados, anteras monotecas ou bitecas, com deiscência rimosa longitudinal, transversal ou poricida, apicais extrorsas ou introrsas, amarelas ou lilases. Ovário súpero, bilocular, placentação axilar, multiovulado; estilete simples; estigma apical capitado, clavado ou bífido. Fruto cápsula ou baga, por vezes envolvidos pelo cálice acrescente, sementes poucas a numerosas.

Na Serra Negra a família Solanaceae está representada por oito gêneros e 26 espécies: Athenaea (1), Aureliana (1), Brugmansia (1), Cestrum (1), Dyssochroma (1), Nicotiana (1), Physalis (1) e Solanum (19).

\section{Chave para identificação das espécies de Solanaceae na Serra Negra}

1. Corola hipocrateriforme ou infundibuliforme; cálice tubuloso ou campanulado.

2. Flor solitária.

3. Arvoreta; flores com corola alva; bractéolas ausentes 3. Brugmansia suaveolens

3'. Epífita ou hemiepífita; flores com corola verde; bractéolas presentes

5. Dyssochroma viridiflora

2'. Flores agrupadas em inflorescências.

4. Inflorescência dicotômica ramificada; bractéolas aciculares 6. Nicotiana tabacum

4'. Inflorescência helicoidal; bractéolas foliáceas 4. Cestrum bracteatum

1'. Corola rotácea, rotácea-estrelada ou campanulada; cálice rotáceo, campanulado ou cupuliforme. 
5. Anteras com deiscência longitudinal.

6. Corola campanulada; anteras roxas; fruto com cálice inflado

7. Physalis pubescens

6'. Corola rotácea-estrelada; anteras alvas ou alvo-esverdeadas; fruto com cálice não inflado.

7. Ramos e folhas glabros, com pontuações negras; cálice com lacínias denteadas; não acrescente nos frutos

2. Aureliana fasciculata

7'. Ramos e folhas pubescentes a pilosos, sem pontuações negras; cálice com lacínias estreitamente lanceoladas, acrescente no fruto.

1. Athenaea picta

5'. Anteras com deiscência poricida às vezes prolongada basipetamente por fendas longitudinais.

8. Plantas inermes.

9. Ramos e folhas glabros, glabrescentes ou pilosos com tricomas simples; lâminas verdes nas duas faces.

10. Lâminas foliares sem papilas, com domácias pilíferas entre as nervuras na face abaxial

19. Solanum pseudoquina

10'. Lâminas foliares com papilas, sem domácias pilíferas entre as nervuras.

11. Corola lilás; anteras coniventes com escamas papilosas

14. Solanum luridifuscescens

11'. Corola alvo-esverdeada; anteras livres, glabras

16. Solanum melissarum

9'. Ramos e folhas com tricomas equinóides, estrelados ou lepidotos; lâminas com a face adaxial verde e a abaxial alva ou alvo-esverdeada.

12. Corola rotáceo-pentagonal, lilás

23. Solanum subumbellatum

12'. Corola rotáceo-estrelada, alva.

13. Lâminas foliares com o ápice involuto

10. Solanum cinnamomeum

13'. Lâminas foliares com o ápice não involuto.

14. Inflorescência monocásio reduzido

24. Solanum swartzianum

14'. Inflorescência dicotômica ramificada.

15. Ramos lepidotos ou glabrescentes, tricomas peltados

13. Solanum leucodendron

15'. Ramos tomentosos, tricomas equinóides.

16. Lâminas foliares com base cuneada; ovário glabro, estigma profundamente bífido 21. Solanum sellowianum

16' Lâminas foliares com base obtusa; ovário com região apical tomentosa, estigma capitado

8. Solanum bullatum

8'. Plantas armadas.

17. Ramos glabrescentes, pubescentes, viscosos ou pilosos com tricomas simples e/ou glandulares.

18. Lâminas foliares com base cordada; inflorescência monocásio reduzido.

19. Corola verde ou alva; ovário glabro; fruto vermelho.

19'. Corola roxa; ovário piloso; fruto verde rajado de amarelo

9. Solanum capsicoides

17. Solanum palinacanthum

18'. Lâminas foliares com base truncada ou assimétrica; inflorescência escorpióide.

20. Ramos cilíndricos, viscosos; corola rotáceo-pentagonal, cálice acrescente nos frutos 22. Solanum sisymbriifolium

20'. Ramos quadrangulares, glabrescentes; corola rotáceo-estrelada, cálice não acrescente nos frutos 25. Solanum vaillantii

17'. Ramos tomentosos com tricomas equinóides ou estrelados ramificados.

21. Liana; ramos e lâminas foliares com acúleos uncinados

20. Solanum schizandrum

21'. Arbusto ou arvoreta a árvore; ramos e lâminas foliares sem a presença de acúleos uncinados.

22. Lâminas foliares com a face abaxial alvo-esverdeada; corola violácea.

23. Lâminas foliares com o ápice arredondado; cálice não acrescente no fruto ....

5. Solanum lycocarpum 
23'. Lâminas foliares com o ápice acuminado, raro obtuso; cálice acrescente no fruto

12. Solanum leptostachys

22'. Lâminas foliares com a face abaxial ferrugínea; corola alva.

24. Inflorescência umbeliforme

18. Solanum piluliferum

24'. Inflorescência dicotomicamente ramificada.

25. Corola rotáceo-estrelada; fruto com cálice não acrescente

11. Solanum decorum

25'. Corola rotáceo-pentagonal; fruto com cálice acrescente cobrindo o terço basal do fruto 26. Solanum velleum

Athenaea Sendtn.

1. Athenaea picta Sendtn. in Mart., Eichler \& Urban, Fl. bras. 10: 134. $1846 . \quad$ Fig. $1 \mathrm{a}-\mathrm{b}$

Arvoreta; ramos cilíndricos, inermes, pubescentes a pilosos, tricomas glandulares. Folhas geminadas, raro isoladas; pecioladas; lâmina membranácea, as maiores 5,7-9 ×3,5-4,6 $\mathrm{cm}$, as menores $1,5-4,5 \times 1-2,3 \mathrm{~cm}$, lanceolada a ovada, ápice agudo a acuminado, base assimétrica, margem sinuada, faces adaxial verde e abaxial verde-clara, pubescentes, tricomas simples e glandulares, acúleos ausentes. Inflorescência fascículo. Flores pediceladas; bractéolas ausentes; cálice rotáceo, lacínias estreitamente lanceoladas; corola rotáceoestrelada, alva, matizada de roxo na face adaxial, 1-1,7 cm diâm., lacínias 5×2-3 mm, obtusas, ápice agudo, piloso com tricomas simples, raro glandulares, faces abaxial e adaxial glabrescentes. Estames 5, isodínamos; filetes ca. $1 \mathrm{~mm}$ compr.; anteras alvas, 2-3 $\mathrm{mm}$ compr., oblongas, deiscência longitudinal. Ovário ca. 2 mm diâm., ovado, glabro; estilete ca. $3 \mathrm{~mm}$ compr., curvo, glabro; estigma capitado. Fruto baga, 1,2-1,4 cm compr., 4-7 mm diâm., ovado, apiculado, pubescente, às vezes glabro; cálice acrescente, lacínias cobrindo o fruto.

Material examinado: Serra Negra, estrada para o Vilarejo do Funil, IX.2004, fl., C.N. Matozinhos et al. 107 (CESJ). Material adicional examinado: ESPÍRITO SANTO: Reserva Biológica Augusto Ruschi, 01.VIII.2002, fl. e fr., R.R. Vervloet et al. 629 (BHCB, MBML).

Athenaea picta distingue-se das demais espécies estudadas pela presença de flores com corola alva matizada de roxo na face adaxial, pela expressiva presença de tricomas glandulares nos ramos, folhas e flores e pelos frutos apiculados. $\mathrm{Na}$ Serra Negra foi encontrada apenas em borda de mata ciliar a $900 \mathrm{~m}$ de altitude. Ocorre nos estados do Espírito Santo, Minas Gerais, Rio de Janeiro, São Paulo e Paraná (Carvalho 1997).
Aureliana Sendtn.

2. Aureliana fasciculata Sendtn. in Mart., Eichler \& Urban, Fl. bras.10: 140. $1846 . \quad$ Fig. 1c-d Arvoreta; ramos cilíndricos, inermes, glabros, com pontuações negras ao longo do caule. Folhas isoladas, raro geminadas; pecioladas; lâmina membranácea, $(2,2-) 5,5-9,3 \times(0,8) 1,6-3,1 \mathrm{~cm}$, lanceolada a estreitamente elíptica, ápice acuminado a cuspidado, base cuneada a atenuada, raramente assimétrica, margem inteira, faces adaxial e abaxial verdes, glabras, com pontuações negras, acúleos ausentes. Inflorescência fascículo. Flores pediceladas; bractéolas ausentes; cálice campanulado, lacínias denteadas; corola rotáceo-estrelada, alva, com manchas basais magentas na face adaxial, 1,1-1,4 cm diâm., lacínias triangulares, ápice agudo, margem glabra a ciliada, tricomas simples; face abaxial e adaxial glabras. Estames 5, heterodínamos, 3 maiores e 2 menores; filetes 3-4 mm compr.; anteras alvo-esverdeadas, 1-2 $\mathrm{mm}$ compr., oblongas, deiscência longitudinal. Ovário 1-2 mm diâm., subgloboso, glabro; estilete ca. $7 \mathrm{~mm}$ compr., reto, glabro; estigma capitado. Fruto baga, ca. 3 mm diâm., imaturo, globoso, glabro; cálice não acrescente.

Material examinado: Serra Negra, Cânion próximo à Gruta do Funil, XI.2005, fl. e fr., K. Antunes et al. 208 (CESJ); Mata do Benedito, ca. 1.000 m, XI.2006, fl., A.S M. Valente \& P.O. Garcia 514 (CESJ).

Aureliana fasciculata pode ser reconhecida pelos ramos e folhas glabros com pontuações negras, pelas flores com manchas basais magentas na face adaxial e pelo cálice com lacínias denteadas. Na Serra Negra foi encontrada em um local bastante úmido no interior de uma mata de encosta, a $1000 \mathrm{~m}$ de altitude. Ocorre na Argentina, Paraguai e Brasil, nos estados do Acre, Bahia, Espírito Santo, Minas Gerais, Rio de Janeiro, São Paulo, Paraná e Santa Catarina (Hunziker \& Barboza 1990). É considerada rara no estado de Minas Gerais (Oliveira-Filho 2006). 

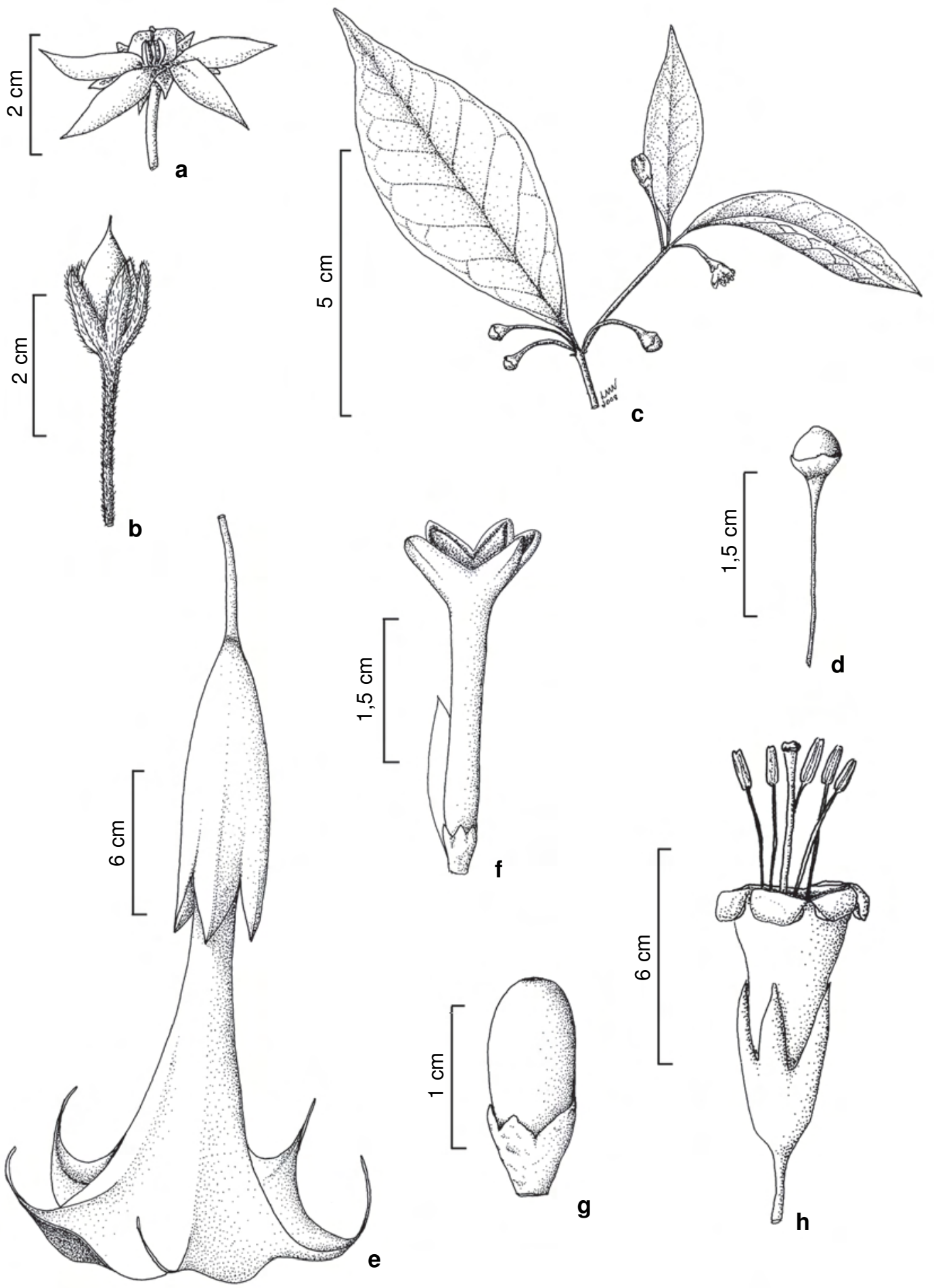

Figura 1 - a-b. Athenaea picta - a. flor; b. fruto apiculado. c-d. Aureliana fasciculata - c. ramo com inflorescência; d. fruto. e. Brugmansia suaveolens - flor. f-g. Cestrum bracteatum - f. flor; g. fruto. h. Dyssochroma viridiflora - flor (a-b Matozinhos 107; c-d Antunes 208; e Feliciano 51; f-g Feliciano 28; h Matozinhos 21).

Figure 1 - a-b. Athenaea picta - a. flower; b. apiculate fruit. c-d. Aureliana fasciculata - c. branch with inflorescence; d. fruit. e. Brugmansia suaveolens - flower. f-g. Cestrum bracteatum - f. flower; g. fruit. h. Dyssochroma viridiflora - flower (a-b Matozinhos 107; c-d Antunes 208; e Feliciano 51; f-g Feliciano 28; h Matozinhos 21). 


\section{Brugmansia Persoon}

3. Brugmansia suaveolens (Willd.) Bercht. \& C. Presl, Prir. Rostlin Aneb. Rostl. 1: 45. 1823. Fig. 1e

Arvoreta; ramos cilíndricos, inermes, glabrescentes, raro com tricomas simples. Folhas isoladas; pecioladas; lâmina cartácea, (6,5-)12-22,2 $\times(1-) 6,1-11,4 \mathrm{~cm}$, ovada a lanceolada, ápice agudo a acuminado, base assimétrica, margem inteira, levemente sinuada, faces adaxial e abaxial verdes, pubescentes a pilosas, tricomas simples, raro glandulares, acúleos ausentes. Flores solitárias, terminais; pediceladas; bractéolas ausentes; cálice tubuloso, inflado, lacínias obtusas; corola infundibuliforme, alva, $25-29 \mathrm{~cm}$ compr., ca. $13,5 \mathrm{~cm}$ diâm., lacínias longamente caudadas, face abaxial pubescente, face adaxial glabrescente. Estames 5, isodínamos; filetes ca. 4,7 cm compr.; anteras alvas, ca. $3 \mathrm{~cm}$ compr., laminares, deiscência longitudinal. Ovário 1-2 mm diâm., fusiforme, glabro; estilete ca. $16,6 \mathrm{~cm}$ compr., reto, glabro; estigma oblongo a globoso. Fruto não visto.

Material examinado: Serra Negra, Vilarejo do Funil, 29.IV.2007, fl., E. A. Feliciano et al. 51 (CESJ); Fazenda Santa Luiza, VI.2007, fl., F.R.G. Salimena \& P. H. Nobre 2476 (CESJ).

Brugmansia suaveolens pode ser facilmente distinta das demais espécies estudadas pelas flores grandes e pêndulas, com corola infundibuliforme, lacínias com ápice longamente caudado e estames com filetes longos, pilosos na metade proximal e anteras laminares. Na Serra Negra é encontrada próximo às margens de cursos d'água em locais bastante iluminados. Essa espécie é amplamente distribuída no Brasil, ocorrendo também em outros países da América do Sul, América Central e África (Smith \& Downs 1966). Apesar de ser uma espécie emplamente distribuída no Brasil não foram encontrados frutos nos materiais analisados em herbário, possivelmente por serem volumosos, chegando a 20 $\mathrm{cm}$, como citado por Carvalho \& Bovini (2006).

\section{Cestrum L}

4. Cestrum bracteatum Link \& Otto, Icon. Pl. Rar. [Link \& Otto] 11: 6. 1828.

Fig. 1f-g

Arbusto ou arvoreta; ramos cilíndricos, inermes, glabros. Folhas isoladas; pecioladas; lâmina membranácea, 10,4-16,5 × 3,2-4 cm., estreitamente elíptica, raro oblonga, ápice acuminado, raro agudo e cuspidado, base atenuada, margem inteira, levemente revoluta, face adaxial e abaxial verdes, glabras, acúleos ausentes. Inflorescência helicoidal, axilar. Flores sésseis; bractéolas foliáceas, caducas, $0,8-1,7 \times 0,5-0,9 \mathrm{~cm}$, ovadas; cálice tubuloso, lacínias triangulares; corola hipocrateriforme, verde, ca. 2,7 cm compr., ca. 1,3 cm diâm., glabro, ápice do tubo ligeiramente giboso; lacínias lanceoladas, ápice arredondado a agudo; face abaxial pilosa, tricomas simples; face adaxial glabra. Estames 5, isodínamos, filetes ca. $5 \mathrm{~mm}$ compr.; anteras, ca. $1 \mathrm{~mm}$ compr., ovadas, deiscência longitudinal. Ovário ca. 2 mm diâm., ovado, glabro; estilete ca. 2,3 cm compr., reto, glabro; estigma capitado. Fruto baga, atropurpúrea, ca. $8 \mathrm{~mm}$ compr., 5-6 mm diâm., globoso a oblongo, glabro; cálice não acrescente.

Material examinado: Serra Negra, Vilarejo do Funil, 2.VI.2006, fl., F.R.G. Salimena et al. 1355 (CESJ); 16.III.2007, fl. e fr., E.A. Feliciano et al. 28 (CESJ); 27.IV.2007, fl., E.A. Feliciano et al. 42 (CESJ).

Cestrum bracteatum pode ser reconhecida pela presença de bractéolas foliáceas, flores verdes, sésseis, pequenas, com corola hipocrateriforme, e pelos ramos, folhas e frutos glabros. Na Serra Negra pode ser encontrada no interior de matas de grota e em áreas de transição de mata e campo rupestre, a aproximadamente $930 \mathrm{~m}$ altitude. Ocorre nos estados do Pernambuco, Minas Gerais, Espírito Santo, Rio de Janeiro, São Paulo, Paraná e Rio Grande do Sul, em altitudes que variam de 500 a $2.000 \mathrm{~m}$.

\section{Dyssochroma Miers}

5. Dyssochroma viridiflora Miers, Ann. Mag. Nat. Hist. ser. 2, 4(22): 251. 1849.

Fig. $1 \mathrm{~h}$

Epífita ou hemiepífita; ramos angulosos, inermes, glabros. Folhas isoladas; pecioladas; lâmina cartácea, 7-15×2,1-4,3 cm, oblanceolada a elíptica, ápice agudo a cuspidado, base atenuada, margem inteira, ligeiramente crenada, faces adaxial e abaxial verdes, glabras, com domácias pilíferas na axila das nervuras secundárias na face abaxial, acúleos ausentes. Flor solitária, terminal, pedicelada; bractéolas ausentes; cálice campanulado, profundamente 4-partido, lacínias triangulares; corola infundibuliforme, verde, ca. 6 cm compr., ca. 3,5 cm diâm., lacínias lanceoladas, revolutas; faces abaxial e adaxial glabras. Estames 5, isodínamos; filetes ca. 7,2 cm compr.; anteras ca. 1,3 cm compr., lineares, deiscência longitudinal. Ovário ca. $7 \mathrm{~cm}$ compr., ca. $5 \mathrm{~cm}$ diâm., subgloboso, glabro; estilete ca. $9 \mathrm{~cm}$ compr., reto, glabro; estigma capitado. Fruto baga, 3-5,2 cm diâm., globoso, apiculado, glabro; cálice acrescente, lacínias cobrindo mais da metade do fruto.

Material examinado: Serra Negra, interior do Cânion do Funil, 20.VIII.2004, fl., C.N. Matozinhos et al. 21 (CESJ). 
Material adicional examinado: MINAS GERAIS: Ouro Preto, Cachoeira das Andorinhas, 9.II.1985, fl. e fr., M. F. Vieira et al. 121 (VIC).

Dyssochroma viridiflora destaca-se pelo hábito epífitico ou hemiepífitico, podendo ser facilmente reconhecida pela corola esverdeada com lacínias revolutas e bagas apiculadas. Na Serra Negra pode ser encontrada em locais bastante úmidos, no interior de matas de grota, a cerca de $990 \mathrm{~m}$ de altitude. Ocorre nos estados da Bahia, Espírito Santo, Minas Gerais, Rio de Janeiro e São Paulo.

\section{Nicotiana L.}

6. Nicotiana tabacum L., Sp. Pl. 1: 180. 1753.

Fig. 2a-b

Erva; caule cilíndrico, inerme, pubescente com tricomas simples e glandulares. Folhas isoladas; pecíolo curto a séssil; lâmina membranácea, 6-20 × 0,7-7 cm, oblongo-lanceolada a elíptica, ápice acuminado, base decorrente, margem sinuada, faces adaxial e abaxial verdes, pubescentes com papilas, tricomas simples e glandulares, acúleos ausentes. Inflorescência dicotômica ramificada, terminal. Flores pediceladas; bractéolas aciculares, 0,5-1,2 cm compr., pubescente; cálice tubuloso, lacínias aciculares; corola infundibuliforme, dilatada no ápice, esverdeada ca. 4,5 cm compr., ca. 1,5 cm diâm., lacínias róseas, reflexas, aciculares, face abaxial pilosa e adaxial pubescente. Estames 5, heterodínamos, 2 maiores e 3 menores; filetes ca. 3 cm compr.; anteras alvas, ca. 3 mm compr., ovadas, deiscência longitudinal. Ovário ca. 7 mm compr., ca. $3 \mathrm{~mm}$ diâm., ovado, glabro; estilete ca. $4 \mathrm{~cm}$ compr., reto, glabro; estigma capitado. Fruto cápsula, verde, 2-2,3 cm compr., ca. $1 \mathrm{~cm}$ diâm., ovado, glabro, ápice apiculado; cálice acrescente, cobrindo mais da metade do fruto.

Material examinado: Serra Negra, Vilarejo do Funil, 21.V.2004., fl. e fr., F.R.G. Salimena et al. 1321 (CESJ).

Nicotiana tabacum possui folhas com pecíolos curtos a séssseis com base decorrente, bractéolas aciculares e flores com corola infundibuliforme, com lacínias róseas curtas. Na Serra Negra pode ser encontrada em ambientes antropizados.

\section{Physalis L.}

\section{Physalis pubescens L., Sp. Pl. 1: 183. 1753.}

Fig. 2c-d

Arbusto; ramos subcilíndricos a angulosos, inermes, pubescentes com tricomas simples. Folhas geminadas; pecioladas; lâmina membranácea, 3,5$8,1 \times 2,3-5,8 \mathrm{~cm}$, ovada, ápice agudo a acuminado, base subtruncada a cordada, margem levemente e irregularmente lobada, lobos às vezes agudos, glabros, faces adaxial e abaxial verdes, velutinas, tricomas simples, acúleos ausentes. Flor solitária, axilar; pedicelada; bractéolas ausentes; cálice campanulado, lacínias reflexas, lanceoladas; corola campanulada, amarela, matizada de roxo na face adaxial, ca. $1 \mathrm{~cm}$ compr., ca. 1,2 cm diâm., lacínias arredondadas, face abaxial pilosa, face adaxial pilosa até a $1 / 2$ do tubo, tricomas glandulares. Estames 5, isodínamos; filetes ca. $3 \mathrm{~mm}$ compr.; anteras roxas, ca. 4 mm compr., oblongas, deiscência longitudinal. Ovário ca. 2 mm diâm., globoso, glabro; estilete roxo, ca. $7 \mathrm{~mm}$ compr., reto, glabro; estigma capitado. Fruto baga, amarelo, 1-1,5 cm diâm., globoso, glabro; cálice acrescente, inflado, cobrindo todo o fruto, ca. $4 \mathrm{~cm}$ compr., ca. $3 \mathrm{~cm}$ diâm., piloso.

Material examinado: Serra Negra, Fazenda Santa Luiza, 31.VI.2007, fl. e fr., F.R.G. Salimena \& P.H. Nobre 2474 (CESJ).

Physalis pubescens possui flores com corola amarela matizada de roxo na face adaxial, anteras roxas e fruto com cálice acrescente e inflado cobrindo todo o fruto. Na Serra Negra foi encontrada apenas em áreas antropizadas. No Brasil, P. pubescens ocorre nos estados de Goiás, Pernambuco, Bahia, Minas Gerais, Rio de Janeiro, São Paulo, Paraná, Santa Catarina e Rio Grande do Sul.

\section{Solanum L.}

8. Solanum bullatum Vell., Fl. Flumin.: 84. 1829, Icon. 2: 104. 1831.

Fig. 2e-f

Arvoreta ou árvore; ramos cilíndricos, inermes, tomentosos com tricomas equinóides. Folhas isoladas; pecioladas; lâmina membranácea, 11,3-17,5 $\times 3,3-6,7 \mathrm{~cm}$, lanceolada a elíptica, ápice acuminado, base obtusa, margem inteira, levemente sinuosa, face adaxial verde, pilosa com tricomas estrelados, peltados, face abaxial alvo-esverdeada, flocosa com tricomas equinóides e estrelados ramificados, acúleos ausentes. Inflorescência dicotômica ramificada, terminal e axilar. Flores curto-pediceladas a sésseis; bractéolas ausentes; cálice cupuliforme, lacínias triangulares; corola rotáceo-estrelada, alva, 1,8-2,3 cm diâm., lacínias triangulares, ápice mucronado, face abaxial tomentosa, face adaxial glabra. Estames 5, isodínamos; filetes ca. 2 mm compr.; anteras amarelas, ca. $4 \mathrm{~mm}$ compr., oblongas, deiscência poricida, prolongada por fendas longitudinais. Ovário ca. 2 mm diâm., globoso, tomentoso no ápice; estilete ca. $7 \mathrm{~mm}$ compr., ligeiramente curvo, glabrescente; estigma capitado. Fruto baga, 0,5-1 cm diâm., globoso, pubescente; cálice acrescente, cobrindo até a metade do fruto. 
Material examinado: Serra Negra, Mata do Ninho da Égua, 04.IV.2006, bot., A.S.M. Valente \& P.O. Garcia 502 (CESJ).

Material adicional examinado: MINAS GERAIS: Marliéria, Parque Estadual do Rio Doce, 02.XII.1997, fl. e fr., M.G. Bovini 1253 (VIC).

Solanum bullatum pode ser reconhecida pelo indumento flocoso, com tricomas equinóides e estrelados ramificados na face abaxial das lâminas foliares. Na Serra Negra pode ser encontrada em interior de mata nebular, a cerca de $1300 \mathrm{~m}$ de altitude. Ocorre na Região Sudeste do Brasil e nos estados do Paraná e Santa Catarina (Smith \& Downs 1966).

9. Solanum capsicoides All., Auct. Syn. Meth. Stirp. Hort. Regii Taur.: 12. $1773 . \quad$ Fig. $2 \mathrm{~g}$

Erva; caule cilíndrico, armado, piloso, com tricomas simples, longos e glandulares; acúleos aciculares. Folhas isoladas, raro geminadas; pecioladas; lâmina membranácea, 3,5-11,5×2,3$9 \mathrm{~cm}$., ovada, ápice agudo a acuminado, base cordada, margem regularmente lobada com 3 pares de lobos, faces adaxial e abaxial verdes, pilosas, com tricomas simples e glandulares, raro tricomas estrelados, acúleos presentes. Inflorescência monocásio reduzido, extra-axilar. Flores pediceladas; bractéolas ausentes; cálice campanulado, lacínias triangulares; corola rotáceoestrelada, verde ou alva, ca. $9 \mathrm{~mm}$ compr., ca. $1,5 \mathrm{~cm}$ diâm., lacínias lanceoladas, ápice mucronado, involuto, face abaxial pilosa, tricomas simples e glandulares; face adaxial glabra. Estames 5, isodínamos, filetes ca. $1 \mathrm{~mm}$ compr.; anteras amarelo-claras, 6-7 $\times 3 \mathrm{~mm}$, lanceoladas, deiscência poricida, prolongada por fendas longitudinais. Ovário 1-2 mm diâm., subgloboso, glabro; estilete ca. $2 \mathrm{~mm}$ compr. nas flores brevestilas, reto, glabro; estigma capitado. Fruto baga, vermelho, 2,5-5 cm diâm., globoso, glabrescente; cálice não acrescente. Material examinado: Serra Negra, Vilarejo do Funil, 26.I.2007, fl., E.A. Feliciano et al. 20 (CESJ); 18.III.2007, fl. e fr., E.A. Feliciano et al. 39 (CESJ); 28.IV.2007, fr., E.A. Feliciano et al. 47 (CESJ).

Solanum capsicoides possui lâminas foliares com margem regularmente lobada, ovário e estilete muito curtos e glabros e frutos grandes, vermelhos quando maduros. Na Serra Negra pode ser encontrada próximo à borda de matas e estradas, em área de pastagem e em campo rupestre. Ocorre em áreas tropicais da América Central e da América do Sul (Nee 1999). No Brasil S. capsicoides é amplamente distribuída, onde ocorre do Ceará até o Paraná.
10. Solanum cinnamomeum Sendtn. in Mart., Eichler \& Urban, Fl. bras.10: 44. $1846 . \quad$ Fig. 3a-d Árvore; ramos cilíndricos, inermes, lepidotos com tricomas peltados. Folhas isoladas; pecioladas; lâmina cartácea, (3-)6,6-10,7×2-2,3 cm; oblonga a lanceolada, ápice acuminado, involuto, base obtusa, assimétrica, margem inteira, face adaxial verde-escura, glabrescente, face abaxial alva, tomentoso-lepidota, tricomas peltados, acúleos ausentes. Inflorescência dicotômica ramificada, terminal. Flores pediceladas; bractéolas ausentes; cálice campanulado, lacínias triangulares; corola rotáceo-estrelada, alva, ca. 1,4 cm compr., ca. $1,8 \mathrm{~cm}$ diâm., lacínias oblongas, face abaxial pubescente, face adaxial glabra. Estames 5, isodínamos; filetes ca. 2-3 mm compr.; anteras amarelas, ca. $3 \mathrm{~mm}$ compr., oblongas, deiscência poricida, não prolongada por fendas longitudinais. Ovário 1-2 mm diâm., ovado, glabro; estilete ca. $7 \mathrm{~mm}$ compr., reto, pubescente; estigma capitado. Fruto baga, verde, 1-1,3 cm diâm., globoso, glabro; cálice não acrescente.

Material examinado: Serra Negra, Serra da Caveira D’Anta, Faz. Tiririca, 25.II.2004, fl., K. Antunes et al. 56 (CESJ); Mata do Ninho da Égua, 04.IV.2006, fr., A.S.M. Valente \& P.O. Garcia 416 (CESJ).

Solanum cinnamomeum destaca-se das demais espécies de Solanum da Serra Negra por apresentar lâminas foliares com o ápice involuto. $\mathrm{Na}$ Serra Negra pode ser encontrada na borda e no interior de matas de encosta e matas nebulares, a 1000-1300 m altitude. Ocorre nos estados Minas Gerais, Espírito Santo, Rio de Janeiro, São Paulo e Paraná. Solanum cinnamomeum é considerada muito rara em Minas Gerais (Oliveira-Filho 2006).

11. Solanum decorum Sendtn., in Mart., Eichler \& Urban, Fl. bras.10: 83. 1846.

Fig. 3e-g

Arvoreta; ramos cilíndricos, armados, tomentosos, com tricomas equinóides, ferrugíneos; acúleos aciculares. Folhas isoladas; pecioladas; lâmina cartácea, (2-)6-14 × (0,7-)2,1-3,9 cm; oblongo-lanceolada a elíptica, ápice agudo a acuminado, base atenuada a decorrente às vezes assimétrica, margem inteira, levemente sinuosa, face adaxial verde, escabra com tricomas estrelados, peltados, face abaxial ferrugínea, tomentosa com tricomas equinóides, acúleos ausentes. Inflorescência dicotômica ramificada, terminal. Flores pediceladas; bractéolas ausentes; cálice campanulado, lacínias triangulares; corola rotáceoestrelada, alva, ca. 1,5-2,2 cm diâm., lacínias lanceoladas, face abaxial pilosa, face adaxial glabra. 


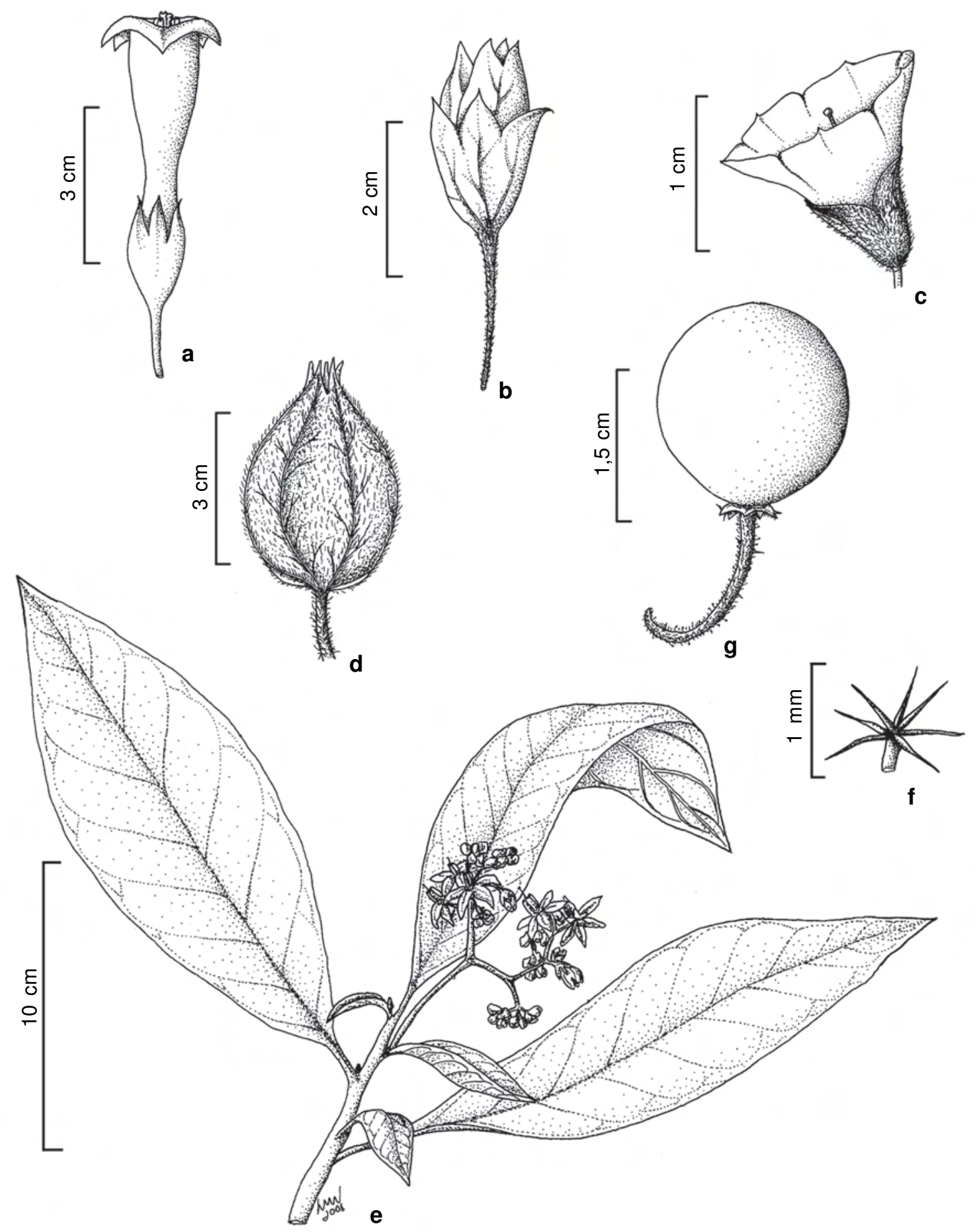

Figura 2 - a-b. Nicotiana tabacum - a. flor; b. fruto. c-d. Physalis pubescens - c. flor; d. fruto. e-f. Solanum bullatum - e. ramo com inflorescência; f. tricoma estrelado ramificado, curto pedicelado. g. S. capsicoides fruto (a-b Salimena 1321; c-d Salimena 2474; e-f Valente 502; g Feliciano 47).

Figure 2 - a-b. Nicotiana tabacum - a. flower; b. fruit. c-d. Physalis pubescens - c. flower; d. fruit. e-f. Solanum bullatum - e. branch with inflorescence; f. stellate hair, short pedicellate. g. S. capsicoides - fruit (a-b Salimena 1321; c-d Salimena 2474; e-f Valente 502; g Feliciano 47). 
Estames 5, isodínamos; filetes ca. $1 \mathrm{~mm}$ compr.; anteras amarelas, ca. $9 \mathrm{~mm}$ compr., lanceoladas, deiscência poricida, prolongada por fendas longitudinais. Ovário ca. 1-2 mm diâm., ovado, piloso com tricomas glandulares; estilete ca. $4 \mathrm{~mm}$ compr., reto, piloso; estigma capitado. Fruto baga, verdes, 1-1,4 cm diâm., globoso, pubescente; cálice não acrescente.

Material examinado: Serra Negra, Vilarejo do Funil, 2.VI.2006, fr., F.R.G. Salimena et al. 1356 (CESJ); 16.III.2007, fr., E.A. Feliciano et al. 29 (CESJ).

Material adicional examinado: MINAS GERAIS: Capelinha, 1000 m, 7.XI.1981, fl., G.C.P. Pinto, 376/ 81 (RB).

Solanum decorum possui ramos ferrugíneos com acúleos inconspícuos, lâminas foliares discolores com face adaxial verde, escabra e abaxial ferrugínea, além de flores com corola rotáceoestrelada. Na Serra Negra foi encontrada principalmente no interior e borda de matas ciliares, a 900 m altitude. É endêmica da Região Sudeste do Brasil (Agra 2000), sendo considerada rara em Minas Gerais (Oliveira-Filho 2006).

12. Solanum leptostachys Dunal in DC., Prodr. 13(1): 306. 1852.

Fig. 4a-e

Árvore; ramos cilíndricos, tomentosos, com tricomas equinóides; acúleos aciculares. Folhas isoladas; pecioladas; lâmina cartácea, 6$11 \times 2,7-4,5 \mathrm{~cm}$, lanceolada a elíptica, raro ovada, ápice acuminado, raro obtuso, base assimétrica, margem sinuosa a irregularmente lobada, faces adaxial e abaxial alvo-esverdeadas, viscosas, com tricomas estrelado-glandulares, ramificados, curto-pedicelados e simplesglandulares, acúleos ausentes. Inflorescência escorpióide, extra-axilar. Flores pediceladas; bractéolas ausentes; cálice campanulado lacínias triangulares; corola rotáceopentagonal, violácea, ca. $1,1 \mathrm{~cm}$ compr., ca. $2 \mathrm{~cm}$ diâm., lacínias triangulares, face abaxial pilosa, face adaxial glabra. Estames 5, isodínamos; filetes 1-2 mm compr.; anteras amarelas, ca. $5 \mathrm{~mm}$ compr., lanceoladas, deiscência poricida, prolongada por fendas longitudinais. Ovário ca. $1 \mathrm{~mm}$ diâm., globoso, piloso; estilete 3-7 mm compr., glabro; estigma bífido. Fruto baga, verde, 0,9-1,2 cm diâm., globoso, pubescente; cálice acrescente, lacínias cobrindo até a metade do fruto.

Material examinado: Serra Negra, Cachoeira da Água Vermelha, 9.IV.2004, fr., K. Antunes et al. 69(CESJ).
Material adicional examinado: BAHIA: Poções, Acesso a Fazenda Boa Esperança com entrada ao Sul de Morinhos, 8.X.2004, fl., A.M. Amorim et al. 4295 (BHCB, CEPEC).

Solanum leptostachys caracteriza-se pelas folhas alvo-esverdeadas, viscosas, com tricomas estrelado-glandulares, e margem sinuosa a irregularmente lobada, de odor forte e inflorescências escorpióides. Na Serra Negra pode ser encontrada em campo rupestre. Ocorre nos estados da Bahia, Minas Gerais, Espírito Santo, Rio de Janeiro e São Paulo.

13. Solanum leucodendron Sendtn., in Mart., Eichler \& Urban, Fl. bras.10: 43. $1846 . \quad$ Fig. 4f

Árvore; ramos cilíndricos, inermes, lepidotos ou glabrescentes, com tricomas peltados. Folhas isoladas; pecioladas; lâmina cartácea, (2-)7,5-16,4 × (0,9-)2,5-5,3 cm, oblonga a estreitamente elíptica, ápice agudo a acuminado, raro retuso, não involuto, base decorrente e revoluta, margem inteira, levemente sinuada, face adaxial verde, glabrescente, face abaxial alva, lepidota, tricomas peltados, acúleos ausentes. Inflorescência dicotômica ramificada, terminal. Flores pediceladas; bractéolas ausentes; cálice cupuliforme, lacínias triangulares; corola rotáceo-estrelada, alva, ca. 9 mm compr., 1,2-1,5 cm diâm., lacínias triangulares, face abaxial lepidota, face adaxial glabra. Estames isodínamos; filetes ca. $1 \mathrm{~mm}$ compr.; anteras amarelas, ca. $3 \mathrm{~mm}$ compr., oblongas, deiscência poricida, prolongada por fendas longitudinais. Ovário ca. $1 \mathrm{~mm}$ diâm., subgloboso, tomentoso no ápice; estilete ca. $5 \mathrm{~mm}$ compr., curvo, pubescente na metade proximal; estigma clavado. Fruto baga, verde, 0,9-1,4 cm diâm., globoso, pubescente; cálice acrescente cobrindo mais da metade do fruto.

Material examinado: Serra Negra, estrada Rio PretoOlaria, 10.XI.2003, fl., F. R. G. Salimena \& P. H. Nobre 1121 (CESJ).

Material adicional examinado: ESPÍRITO SANTO: Venda Nova do Imigrante, Sítio Guaçuvirá, 31.I.1995, fl. e fr., D. A. Folli 2521 (BHCB).

Solanum leucodendron apresenta folhas geralmente grandes, oblongas a estreitamente elípticas, com a face abaxial alva, coberta por tricomas peltados prateados. Na Serra Negra pode ser encontrada em borda de mata, a aproximadamente $1.000 \mathrm{~m}$ altitude. Ocorre nos estados de Minas Gerais, Espírito Santo, Rio de Janeiro e Paraná, em altitudes que variam de 400 a $1.300 \mathrm{~m}$. 


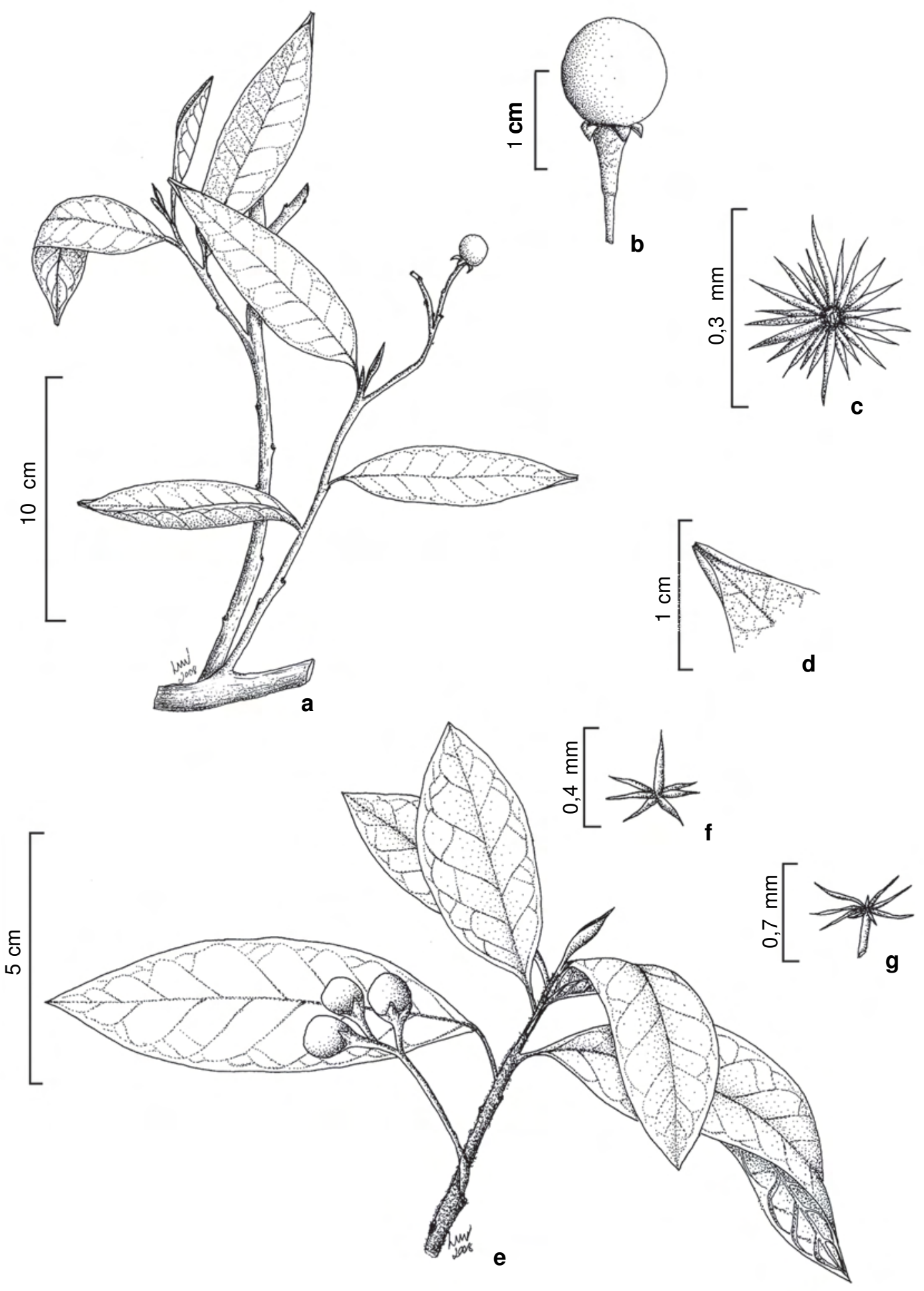

Figura 3 - a-d. Solanum cinnamomeum - a. ramo com fruto; b. fruto; c. tricoma peltado; d. ápice foliar involuto. e-g. S. decorum - e. ramo com frutos; f. tricoma estrelado;g. tricoma equinóide (a-d Antunes 56; e Feliciano 47; f-g Feliciano 29).

Figure 3 - a-d. Solanum cinnamomeum - a. branch with fruit; b. fruit; c. peltate hair; d. leaf involute apex. e-g. S. decorum - e. branch with fruits; f. stellate hair; g. echinate hair (a-d Antunes 56; e Feliciano 47; f-g Feliciano 29). 
14. Solanum luridifuscescens Bitter, Repert. Spec. Nov. Regni Veg. 12: 466. $1913 . \quad$ Fig. 4g

Arbusto; ramos cilíndricos, inermes, glabros com pontuações negras. Folhas isoladas, raro geminadas; pecioladas; lâmina membranácea, 3 $13,5 \times 1,2-4 \mathrm{~cm}$; oblonga a oblanceolada, ápice agudo a acuminado, base decorrente, margem inteira, revoluta, ciliada, com tricomas simples, faces adaxial e abaxial verdes, glabras, com pontuações negras e papilas, esparsas, acúleos ausentes. Inflorescência escorpióide, axilar. Flores pediceladas; bractéolas ausentes; cálice campanulado a cupuliforme, lacínias ovadas, com ápice mucronado, carnoso; corola rotáceoestrelada, lilás, ca. 1,5-2,7 cm diâm., lacínias lanceoladas, ápice agudo, involuto, face abaxial pubescente; face adaxial glabra. Estames 5, isodínamos; filetes subsésseis; anteras amarelas, 8-9 mm compr., lanceoladas, coniventes, com escamas papilosas, deiscência poricida, não prolongada por fendas longitudinais. Ovário ca. 2 mm diâm., ovado, glabro, raramente com tricomas glandulares na base do ovário; estilete ca. $9 \mathrm{~mm}$ compr., reto, glabro; estigma truncado. Fruto baga, 1-1,5 cm diâm., ligeiramente oblongo, glabro, com pontuações negras, raro com tricomas simples; cálice não acrescente.

Material examinado: Serra Negra, Região do Burro de Ouro, 26.II.2006, fr., P.L. Viana \& N.F.O. Mota 1945 (CESJ). Material adicional examinado: RIO DE JANEIRO: Nova Friburgo, Estrada das Torres, 15.IX.1987, fl., Siqueira \& Sobral s.n. (RB 274803).

Solanum luridifuscescens pode ser distinta das demais espécies estudadas pela presença de anteras coniventes com escamas papilosas. $\mathrm{Na}$ Serra Negra pode ser encontrada a aproximadamente $1.500 \mathrm{~m}$ de altitude, no interior de matas nebulares. Espécie endêmica do Brasil, onde ocorre nos estados de Goiás, Minas Gerais, Espírito Santo, Rio de Janeiro, São Paulo e Paraná, em florestas úmidas frequentemente alagadas entre 1.100 e $2.650 \mathrm{~m}$ de altitude (Bohs 2001).

15. Solanum lycocarpum A. St.-Hil., Voy. Distr. Diam. 1 (2): 333. 1833.

Fig. 5a-b

Arvoreta; ramos cilíndricos a quadrangulares, armados, tomentosos, com tricomas equinóides; acúleos aciculares. Folhas isoladas raro geminadas; pecioladas; lâmina cartácea, 9,8-20 ×5,3-10,3 cm; lanceolada, ápice arredondado, base cordada, assimétrica, margem sinuada a lobada, com lobos irregulares redondos, faces adaxial e abaxial, alvo- esverdeadas, densamente pilosas, com tricomas estrelados, ramificados, e equinóides, acúleos presentes. Inflorescência escorpióide, extra-axilar. Flores pediceladas; bractéolas ausentes; cálice campanulado, lacínias lanceoladas; corola rotáceopentagonal, violácea, $3,5-4,5 \mathrm{~cm}$ diâm., lacínias lanceoladas, ápice agudo, faces abaxial e adaxial pubescentes. Estames 5, isodínamos; filetes 2$3 \mathrm{~mm}$ compr.; anteras amarelas, ca. 1,3 cm compr., lanceoladas, deiscência poricida, prolongada por fendas longitudinais. Ovário ca. $1 \mathrm{~mm}$ diâm., globoso, piloso; estilete ca. $3 \mathrm{~mm}$ compr., reto, glabro; estigma capitado. Fruto baga, verde, 4,5$8 \mathrm{~cm}$ diâm., globoso, piloso; cálice não acrescente. Material examinado: Serra Negra, Vilarejo do Funil, 28.I.2007, fl.fr., E.A. Feliciano et al. 21 (CESJ).

Solanum lycocarpum pode ser facilmente reconhecida pelos frutos grandes, cálice não acrescente durante a frutificação e flores vistosas violáceas. Na Serra Negra pode ser encontrada em áreas abertas antropizadas a ca. $900 \mathrm{~m} \mathrm{de}$ altitude. Possui ampla distribuição geográfica, ocorrendo no Paraguai e no Brasil, nos estados do Amazonas, Mato Grosso, Mato Grosso do Sul, Distrito Federal, Goiás, Tocantins, Bahia, Minas Gerais, São Paulo e Paraná.

16. Solanum melissarumBohs, Taxon 44(4): 584.1995. Fig. $5 \mathrm{c}-\mathrm{d}$

Arvoreta; ramos angulosos, inermes, pubescentes, com tricomas simples. Folhas geminadas, raramente três no mesmo nó; pecioladas; lâmina membranácea, as maiores 7,5$17 \times 3,8-4,5 \mathrm{~cm}$ oblongas a lanceoladas, as menores 2,5-5,4 × 1,2-3,2 cm, ovadas, ápice caudado, às vezes agudo e raramente apiculado, base atenuada, assimétrica, margem inteira a levemente sinuada, faces adaxial e abaxial verdes, papilosas e pubescentes, com tricomas simples, acúleos ausentes. Inflorescência escorpióide, extra-axilar ou axilar. Flores pediceladas; bractéolas ausentes; cálice campanulado, profundamente partido, lacínias filiformes; corola rotáceo-estrelada, alvo-esverdeada, ca. 1,5 cm compr., ca. 2,8 cm diâm., lacínias profundamente partidas, lanceoladas, face abaxial pubescente, face adaxial glabra. Estames 5, isodínamos; filetes ca. $1 \mathrm{~mm}$ compr., espessados no ápice; anteras amarelas, ca. $5 \mathrm{~mm}$ compr., lanceoladas, região basal gibosa, deiscência poricida, prolongada por fendas longitudinais. Ovário ca. 4 mm compr., ca. $3 \times 1 \mathrm{~mm}$ diâm., oblongo, pubescente; estilete ca. 


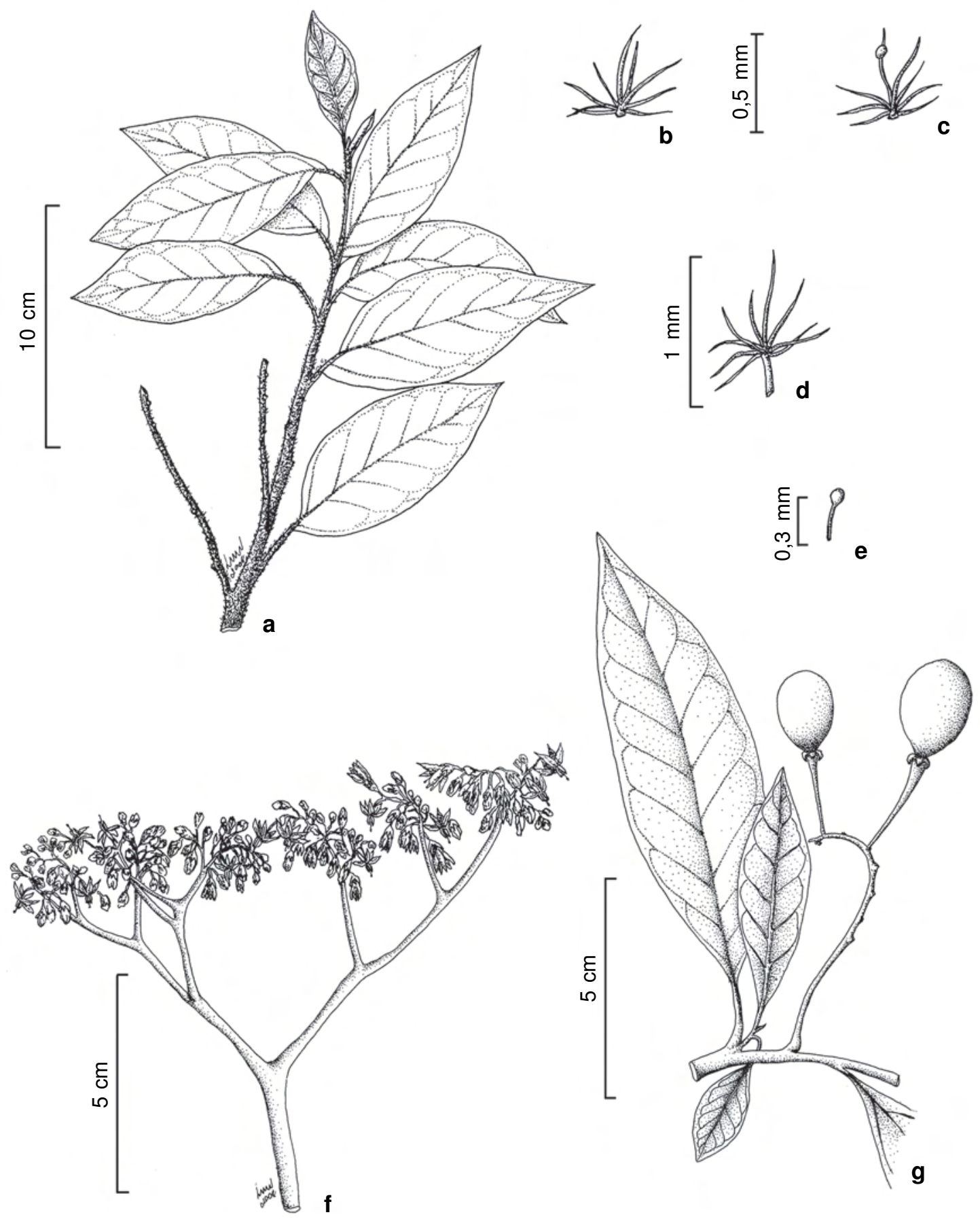

Figura 4 -a-e. Solanum leptostachys - a. detalhe do ramo; b. tricoma estrelado ramificado; c. tricoma estrelado-glandulífero; d. tricoma equinóide; e. tricoma glandular. f. S. leucodendron - inflorescência dicotômica ramificada. g. S. luridifuscescens - ramo com inflorescência escorpióide evidenciando os frutos (a-e Antunes 69; f Salimena 1121; g Viana 1945).

Figure 4 - a-e. Solanum leptostachys - a. branch detail ; b. stellate hair; c. glandular stellate hair; d. echinate hair; e. glandular hair. f. S. leucodendron - dicotomous inflorescence. g. S. luridifuscescens - branch with scorpioid inflorescence highlighting the fruits (a-e Antunes 69; f Salimena 1121; g Viana 1945). 
1-4 mm compr., reto, pubescente; estigma capitado. Fruto baga, 2-3,5 cm compr., ca. 1,52,1 cm diâm., oblongo, glabrescente; cálice às vezes caduco, não acrescente.

Material examinado: Serra das Voltas, Estrada Vilarejo do Funil-Taboão, 27.I.2007, fl., F.R.G. Salimena \& P.H. Nobre 2370 (CESJ).

Material adicional examinado: BAHIA: Ilhéus, Estrada que liga Olivença à Vila Brasil, 16.II.1982, fr., $L$. A. M. Silva et al., s.n. (RB 271845).

Solanum melissarum apresenta flores com corola alvo-esverdeada, com lacínias profundamente partidas, estames com filetes espessados no ápice e cálice caduco durante a frutificação. Pode ser encontrada na Serra Negra em locais sombreados no interior de matas de encosta, a ca. $950 \mathrm{~m}$ de altitude. Ocorre nos estados da Paraíba, Bahia, Espírito Santo, Minas Gerais, Rio de Janeiro, São Paulo, Paraná e Santa Catarina, em elevações de 50 a 800 m (Bohs 1995). Solanum melissarum é considerada muito rara em Minas Gerais (Oliveira-Filho 2006).

17. Solanum palinacanthum Dunal, DC. Prodr. 13 (1): 245.1852.

Fig. 5e

Arbusto; ramos cilíndricos, armados, pubescentes com tricomas simples e glandulares; acúleos aciculares. Folhas isoladas, raro geminadas; pecioladas; lâmina cartácea, 2,5-9 × 1,1-8 cm, ovada, ápice agudo, base cordada, margem irregularmente lobada, face adaxial verdeescura, pilosa com tricomas simples, face abaxial alvo-esverdeada, pilosa com tricomas estrelados, ramificados, sésseis, as duas faces aculeadas. Inflorescência monocásio reduzido, extra-axilar. Flores pediceladas; bractéolas ausentes; cálice cupuliforme a campanulado, lacínias ovadas; corola rotáceo-estrelada, roxa, ca. 2,2 cm compr., 2,6-4 cm diâm., profundamente partida, lacínias estreitamente lanceoladas, face abaxial pilosa, face adaxial glabra. Estames 5, isodínamos; filetes ca. $1 \mathrm{~mm}$ compr.; anteras amarelas, ca. 1,2 cm compr., lanceoladas, deiscência poricida, prolongada por fendas longitudinais. Ovário ca. 1,5 compr., ca. 2 mm diâm., ovado, piloso; estilete ca. 1,6 cm compr., levemente curvo, pubescente na base; estigma capitado. Fruto baga, verde, rajado de amarelo, 3,1-3,6 cm diâm., globoso, glabrescente; cálice não acrescente.

Material examinado: Serra Negra, vilarejo do Funil, 28.I.2007, fl., E.A. Feliciano et al. 22(CESJ).

Material adicional examinado: RIO DE JANEIRO: Barra Mansa, Fazenda do Paraíso, 4.XII.1960, fl. e fr., A. P. Duarte 5840 (RB).
Solanum palinacanthum pode ser distinta das demais espécies estudadas pelas inflorescências congestas com flores grandes (2,5$4 \mathrm{~cm}$ diâm.), com corola roxa e frutos verdes rajados de amarelo, com 3,1-3,6 cm de diâmetro. Na Serra Negra pode ser encontrada em campos rupestres a 990 m de altitude. Ocorre nos estados de Rondônia, Mato Grosso, Goiás, Ceará, Paraíba, Espírito Santo, Minas Gerais, Rio de Janeiro, São Paulo e Paraná, estando presente ainda na Bolívia, Paraguai e nordeste da Argentina (Nee 1999).

18. Solanum piluliferum Dunal, DC. Prodr.13 (1): 265. 1852.

Fig. 5f-h

Arbusto; ramos cilíndricos, armados, tomentosos com tricomas equinóides; acúleos aciculares. Folhas geminadas; pecioladas; lâmina cartácea, as maiores $12-13,8 \times 4,5-6 \mathrm{~cm}$, elípticas a oblongas, ápice acuminado, base assimétrica, margem inteira a levemente sinuada, as menores $2,7-4 \times 2-2,7 \mathrm{~cm}$, ovadas, ápice arredondado, base obtusa, raro truncada, margem inteira, faces adaxial e abaxial ferrugíneas, tomentosas com tricomas equinóides e estrelados sésseis, acúleos ausentes. Inflorescência umbeliforme, axilar. Flores pediceladas; bractéolas ausentes; cálice cupuliforme, lacínias triangulares; corola rotáceo-pentagonal, alva, glabra e membranácea na região entre as lacínias, ca. 1,3 cm compr.; ca. 2,2 cm diâm., lacínias lanceoladas, face abaxial pilosa, face adaxial glabra. Estames 5, isodínamos; filetes ca. $1 \mathrm{~mm}$ compr.; anteras amarelas, ca. $8 \mathrm{~mm}$ compr., lanceoladas, deiscência poricida, às vezes prolongada por fendas longitudinais. Ovário ca. 1,8 cm compr., ca. $2 \mathrm{~mm}$ diâm., globoso, glabro; estilete ca. $1,1 \mathrm{~cm}$ compr., reto, piloso na metade basal; estigma capitado. Fruto baga, verde-amarelado, 1,3-1,6 cm diâm., globoso, glabro; cálice acrescente, cobrindo até a metade do fruto.

Material examinado: Serra Negra, Estrada Rio PretoOlaria, 10.XI.2003, fl., F.R.G. Salimena \& P.H. Nobre 1116 (CESJ); Mata atrás do Cambuí, 26.I.2007, fr., E.A. Feliciano et al. 18 (CESJ).

Solanum piluliferum apresenta como caracteres diagnósticos as inflorescências umbeliformes e as folhas aos pares, de tamanho e forma diferentes, sendo as maiores elípticas a oblongas com ápice acuminado, e as menores ovadas com ápice arredondado. $\mathrm{Na}$ Serra Negra pode ser encontrada em áreas antropizadas entre 900 e $1.035 \mathrm{~m}$ de altitude. Ocorre nos estados da Bahia (Whalen 1984), Minas Gerais, Rio de Janeiro, São Paulo e Paraná. 

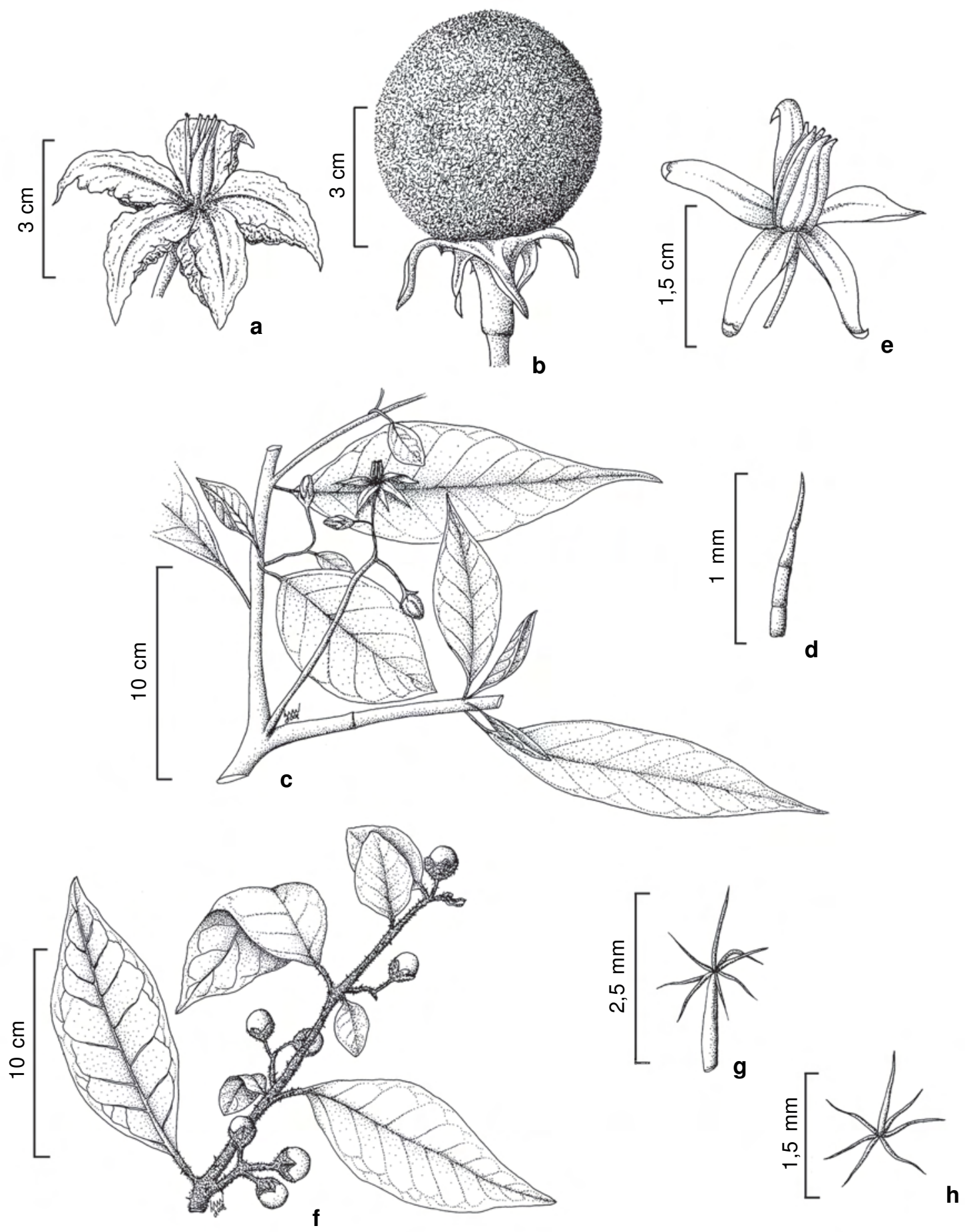

Figura 5 - a-b. Solanum lycocarpum - a. flor (corola rotáceo-pentagonal); b. fruto. c-d. S. melissarum - c. ramo com inflorescência; d. tricoma simples. e. S. palinacanthum - flor (corola rotáceo-estrelada). f-h. S. piluliferum - f. ramo; g. tricoma equinóide; h. tricoma estrelado (a-b Feliciano 21; c-d Salimena 2370; f Feliciano 22; f-h:Feliciano 19).

Figure 5 - a-b. Solanum lycocarpum - a. flower (rotate-pentagonal corolla); b. fruit. c-d. S. melissarum - c. branch with inflorescence; d. simple hair. e. S. palinacanthum - flower (rotate-stellate corolla). f-h. S. piluliferum - f. branch; g. echinate hair; h. stellate hair (a-b Feliciano 21; c-d Salimena 2370; f Feliciano 22; f-h Feliciano 19). 
19. Solanum pseudoquina A. St.-Hil., Pl. Usuel. Bras. 5: t. 21. 1825.

Fig. 6a-c

Árvore; ramos cilíndricos, inermes, glabrescentes. Folhas isoladas e geminadas; pecioladas; lâmina membranácea a cartácea, 4,513,5 ×2,1-3,6 cm, estreitamente elíptica a oblonga, ápice agudo-acuminado, base decorrente, revoluta, margem inteira, face adaxial verde, glabra, face abaxial verde, com domácias pilíferas entre as nervuras, acúleos ausentes. Inflorescência escorpióide, axilar e extra-axilar. Flores pediceladas; bractéolas ausentes; cálice campanulado, lacínias largamente oblonga; corola rotáceo-estrelada, alva, 1-1,3 cm diâm., lacínias lanceoladas, ápice agudo, pubescente com tricomas simples; faces abaxial e adaxial glabras. Estames isodínamos; filetes ca. $1 \mathrm{~mm}$ compr.; anteras amarelas, ca. $3 \mathrm{~mm}$ compr., oblongas, deiscência poricida, às vezes prolongada por fendas longitudinais. Ovário ca. $1 \mathrm{~mm}$ diâm., globoso, glabrescente na base do ovário; estilete ca. $4 \mathrm{~mm}$ compr., curvo, glabro; estigma bilobado. Fruto baga, castanho-amarelado, ca. 1-2 cm diâm., globoso, glabro; cálice não acrescente.

Material examinado: Serra Negra, Estrada Rio PretoOlaria, 10.XI.2003, fr., F.R.G. Salimena \& P.H. Nobre 1119 (CESJ).

Material adicional examinado: MINAS GERAIS: Juiz de Fora, Reserva Biológica Santa Cândida, X.1996, fl., R.C. Almeida-Lafetá 213 (CESJ).

Solanum pseudoquina pode ser reconhecida pela presença de domácias pilíferas na axila das nervuras secundárias na face abaxial da lâmina foliar. Na Serra Negra pode ser encontrada em borda de mata, a aproximadamente $1.035 \mathrm{~m}$ de altitude. Ocorre na Argentina, Brasil, Paraguai e Uruguai (Knapp 2002; Nee 1999). No Brasil estende-se do Espírito Santo até o Rio Grande do Sul (Smith \& Downs 1966).

20. Solanum schizandrum Sendtn., in Mart., Eichler \& Urban, Fl. bras.10: 85. $1846 . \quad$ Fig. 6d-f

Liana; ramos cilíndricos, armados, tomentosos com tricomas equinóides; acúleos uncinados. Folhas isoladas; pecioladas; lâmina cartácea, 9-10,2 × 2,9-3,6 cm, lanceolada a oblonga, ápice agudo, base obtusa, raro truncada, margem inteira, faces adaxial e abaxial verdeferrugíneas, pilosas a tomentosas, com tricomas estrelados, ramificados, curto-pedicelados, bulbosos e equinóides, acúleos presentes. Inflorescência dicotômica ramificada, terminal. Flores pediceladas; bractéolas ausentes; cálice campanulado, lacínias triangulares; corola rotáceo-estrelada, azul, ca. $1,1 \mathrm{~cm}$ compr., ca. 1,5 cm diâm., lacínias obtusas, faces abaxial e adaxial, pilosas. Estames 5, isodínamos; filetes ca. $1 \mathrm{~mm}$ compr.; anteras amarelas, ca. $9 \mathrm{~mm}$ compr., lanceoladas, deiscência poricida, às vezes prolongada por fendas longitudinais. Ovário 1-2 mm diâm., globoso, piloso; estilete ca. 2 mm compr., reto, glabro; estigma capitado. Fruto baga, vermelho, ca. 4,5 cm diâm., globoso, pubérulo; cálice não acrescente.

Material examinado: Serra Negra, Mata do Ninho da Égua, 1.IV.2006, fr., P.L. Viana et al. 2011 (CESJ).

Material adicional examinado: MINAS GERAIS: Juiz de Fora, Reserva Biológica Santa Cândida, 12.X.1996, fl. e fr., R.C. Almeida-Lafeta 206 (CESJ).

Solanum schizandrum é a única liana entre as Solanaceae da Serra Negra. Dentre os caracteres diagnósticos da espécie destacam-se os pequenos acúleos uncinados, as folhas cobertas por tricomas estrelados ramificados curto-pedicelados com base bulbosa e os frutos grandes (ca. 4,5 cm diâm.). $\mathrm{Na}$ área de estudo pode ser encontrada no interior de matas nebulares e em afloramentos rochosos a $1.300 \mathrm{~m}$ de altitude. Ocorre nos estados da Bahia, Espírito Santo, Minas Gerais e Rio de Janeiro.

21. Solanum sellowianum Sendtn., in Mart., Eichler \& Urban, Fl. bras.10: 38. $1846 . \quad$ Fig. 6g

Arvoreta ou árvore; ramos subcilíndricos, inermes, tomentosos com tricomas equinóides. Folhas isoladas; pecioladas; lâmina cartácea, 5$12 \times 2,3-3,5 \mathrm{~cm}$, elíptica a estreitamente elíptica, ápice acuminado a cuspidado, não involuto, base cuneada, assimétrica, margem inteira, revoluta, face adaxial verde-escura, papilosa, glabrescente com tricomas estrelados, ramificados, curtopedicelados, face abaxial alva, tomentosa-velutina com tricomas estrelados e peltados, acúleos ausentes. Inflorescência dicotômica ramificada, terminal. Flores pediceladas; bractéolas ausentes; cálice cupuliforme, lacínias triangulares; corola rotáceo-estrelada, alva, ca. $1,7 \mathrm{~cm}$ compr., ca. $2,3 \mathrm{~cm}$ diâm., lacínias ca. $8 \times 4 \mathrm{~mm}$, lanceoladas, ápice acuminado, involuto, face abaxial pilosa, face adaxial glabra. Estames 5, isodínamos; filetes ca. $1 \mathrm{~mm}$ compr.; anteras amarelas, ca. $6 \mathrm{~mm}$ compr., oblongas, deiscência poricida, prolongada por fendas longitudinais. Ovário $1 \mathrm{~mm}$ diâm., globoso, glabro; estilete ca. $9 \mathrm{~mm}$ compr., ligeiramente curvo, glabro; estigma profundamente bífido. Fruto baga, verde, ca. $1 \mathrm{~cm}$ diâm., globoso, pubescente; cálice acrescente, cobrindo mais da metade do fruto. 


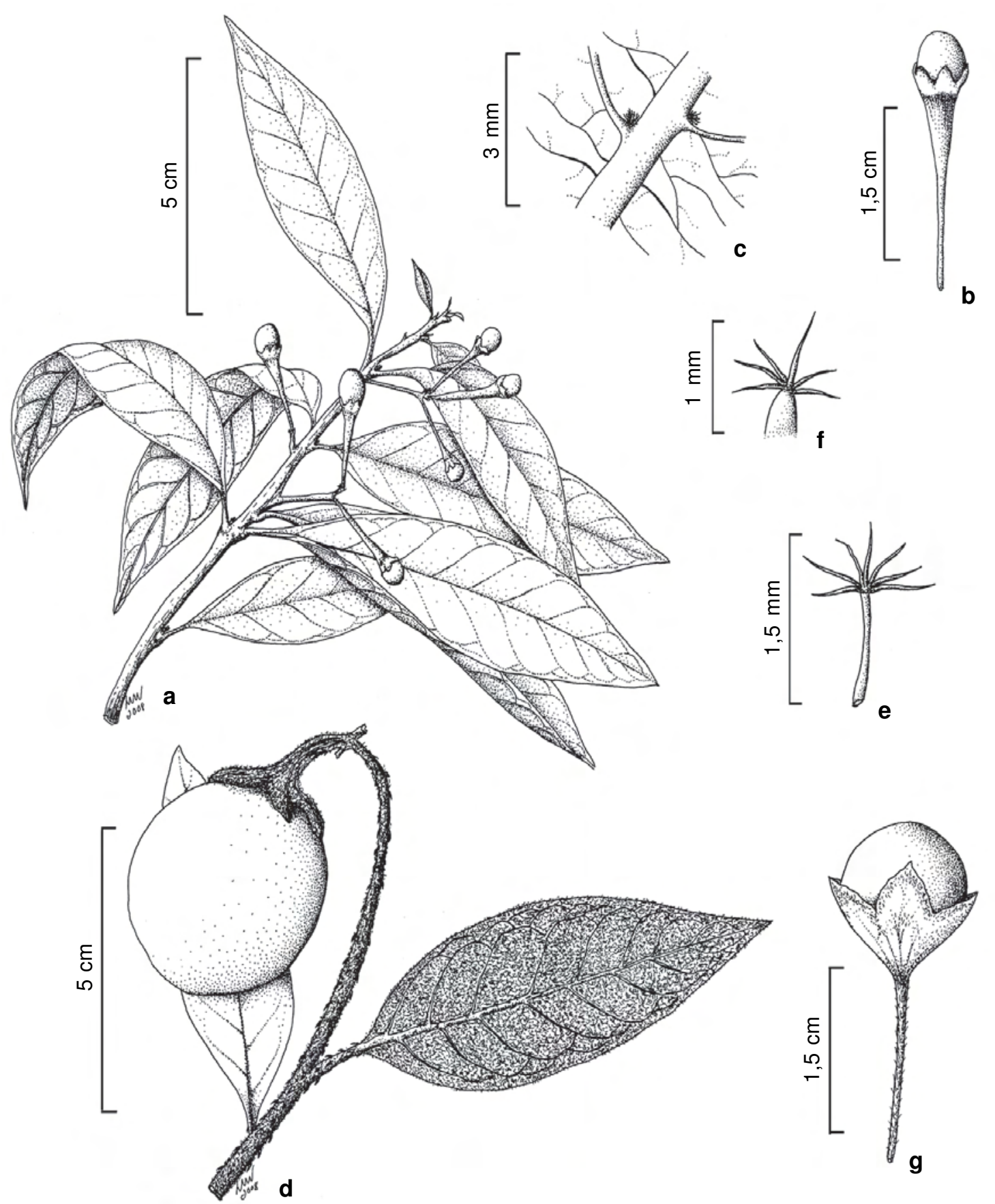

Figura 6 -a-c. Solanum pseudoquina - a. ramo com frutos; b. fruto; c. face abaxial da lâmina foliar evidenciando domácias pilíferas entre as nervuras principal e secundárias. d-f. S. schizandrum-d. ramo; e. tricoma equinóide; f. tricoma estrelado com base bulbosa. g. S. sellowianum - fruto ( a-c Salimena 1119; d-fViana 2011; g Feliciano 25).

Figura 6 - a-c. Solanum pseudoquina - a. branch with fruits; b. fruit; c. leaf abaxial surface highlighting piliferous domatia between primary and secondary veins. d-f. S. schizandrum - d. branch; e. echinate hair; f. stellate hair with bulbose base. g. S. sellowianumfruit (a-c: Salimena 1119; d-f: Viana 2011; g: Feliciano 25). 
Material examinado: Serra da Caveira D'Anta, Fazenda Tiririca, 15.XI.2003, fl., F.R.G. Salimena et al. 1143 (CESJ); Serra Negra, Cachoeira do Ninho da Égua, 1.III.2006, fl. e fr., P.L. Viana et al. 2010 (CESJ).

Solanum sellowianum pode ser reconhecida pela presença de tricomas estrelados nas folhas, inflorescências e frutos, pela inflorescência dicotômica ramificada e pelos frutos parcialmente envolvidos pelo cálice. Na Serra Negra ocorre em campos rupestres, áreas de transição de florestacampo, no interior e borda de matas nebulares e até mesmo na beira de estradas, em altitudes que variam de 900 a 1.300 m. Possui distribuição restrita aos estados de Minas Gerais e São Paulo.

22. Solanum sisymbriifolium Lam., Tabl. Encycl. 2:25. 1794 .

Fig. 7a-d

Arbusto; ramos cilíndricos, armados, viscosos com tricomas simples e glandulares longos; acúleos aciculares. Folhas isoladas, pinatissectas; pecioladas; lâmina membranácea, 4-13,5 ×3,3$7,5 \mathrm{~cm}$, ovada, ápice agudo, base assimétrica, margem irregularmente lobada, denteada, face adaxial verde, pilosa com tricomas simples, glandulares, raro estrelados, face abaxial verde, pilosa com tricomas estrelados, sésseis com célula central longa e curva, raro tricomas simples e glandulares, acúleos presentes. Inflorescência escorpióide, extra-axilar. Flores pediceladas; bractéolas ausentes; cálice campanulado, lacínias lanceoladas; corola rotáceopentagonal, alva, ca. 1,4 cm compr., ca. 2,5 cm diâm., lacínias $0,8 \times 1 \mathrm{~cm}$, obtusas, ápice mucronado, face abaxial pilosa, face adaxial glabra. Estames 5, isodínamos; filetes ca. $2 \mathrm{~mm}$ compr.; anteras amarelas, 5-7 $\mathrm{mm}$ compr., lanceoladas, deiscência poricida, prolongada por fendas longitudinais. Ovário 1-2 mm diâm., globoso, glabro; estilete ca. $2 \mathrm{~mm}$ compr., reto, glabro; estigma bilobado ou capitado. Fruto baga, negro, ca. 1,7 cm diâm., globoso, nítido, glabro; cálice acrescente, as lacínias cobrindo quase inteiramente o fruto.

Material examinado: Serra Negra, Vilarejo do Funil, Taboão antes da Fazenda da Tiririca, 26.I.2006, fl. e fr., F.R.G. Salimena \& P.H. Nobre 2366 (CESJ).

Solanum sisymbriifolium distingue-se das demais espécies estudadas por apresentar folhas pinatissectas com a margem denteada, acúleos aciculares amarelados com base clara e frutos glabros com cálice acrescente e aculeado, cobrindo quase inteiramente o fruto. Na Serra Negra pode ser encontrada em áreas de pastagem.
23. Solanum subumbellatum Vell., Fl. Flumin. 85. 1829, Icon. 2: t. 105. 1831.

Fig. 7e

Arbusto; ramos cilíndricos, inermes, tomentosos com tricomas equinóides. Folhas isoladas; pecioladas; lâmina cartácea, 3,6-8,5× $1,7-3,6 \mathrm{~cm}$, elíptica a oblonga, ápice agudo a acuminado, base levemente assimétrica, margem inteira, face adaxial verde, com pontuações negras, pubescente, face abaxial alva, velutinatomentosa com tricomas estrelados ramificados, pedicelados, acúleos ausentes. Inflorescência escorpióide, terminal. Flores pediceladas; bractéolas ausentes; cálice campanulado, lacínias oblongas; corola rotáceo-pentagonal, lilás, ca. $1,2 \mathrm{~cm}$ compr., ca. $2,2 \mathrm{~cm}$ diâm., lacínias $4 \times 3 \mathrm{~mm}$, lanceoladas, ápice agudo, involuto, face abaxial pilosa, tricomas estrelados, sésseis; face adaxial glabra. Estames 5, isodínamos; filetes 2-3 mm compr.; anteras amarelas, 6-8 $\mathrm{mm}$ compr., lanceoladas, deiscência poricida, prolongada por fendas longitudinais. Ovário ca. $1 \mathrm{~mm}$ diâm., globoso, glabro; estilete 4-10 mm compr., reto, glabro, pubescente na base; estigma capitado e bífido. Fruto baga, pêndulo, 8-10 mm diâm., globoso, glabro; cálice não acrescente.

Material examinado: Serra Negra, Região do Burro de Ouro, 27.I.2007, fl. e fr., L. Menini Neto et al. 302 (CESJ).

Solanum subumbellatum caracteriza-se pelas lâminas foliares discolores, com a face abaxial velutino-tomentosa, com tricomas estrelados, ramificados, flores com a corola rotáceopentagonal lilás e frutos pequenos ( $8-10 \mathrm{~mm}$ diâm.) e pêndulos com cálice não acrescente. Na Serra Negra pode ser encontrada em campos rupestres acima de $1510 \mathrm{~m}$ de altitude. Ocorre no Tocantins, Goiás, Distrito Federal, Mato Grosso do Sul, Minas Gerais e São Paulo.

24. Solanum swartzianum Roem. \& Schult., Syst. Veg. 4:602.1819. Fig. 7f-g

Arvoreta ou árvore; ramos cilíndricos, inermes, escabros, lepidotos com tricomas peltados. Folhas isoladas e geminadas; pecioladas; lâmina cartácea, 3,5-14,3 × 1,9-5 cm; obovada-elíptica a lanceolada, ápice acuminado a cuspidado, não involuto, base cuneada, margem inteira, levemente revoluta, face adaxial, verde-escura, pubescente com tricomas peltados, com célula central longa, face abaxial, alva, lepidota com tricomas peltados, com célula central curta, acúleos ausentes. Inflorescência monocásio reduzido, axilar. Flores pediceladas; bractéolas ausentes; cálice 

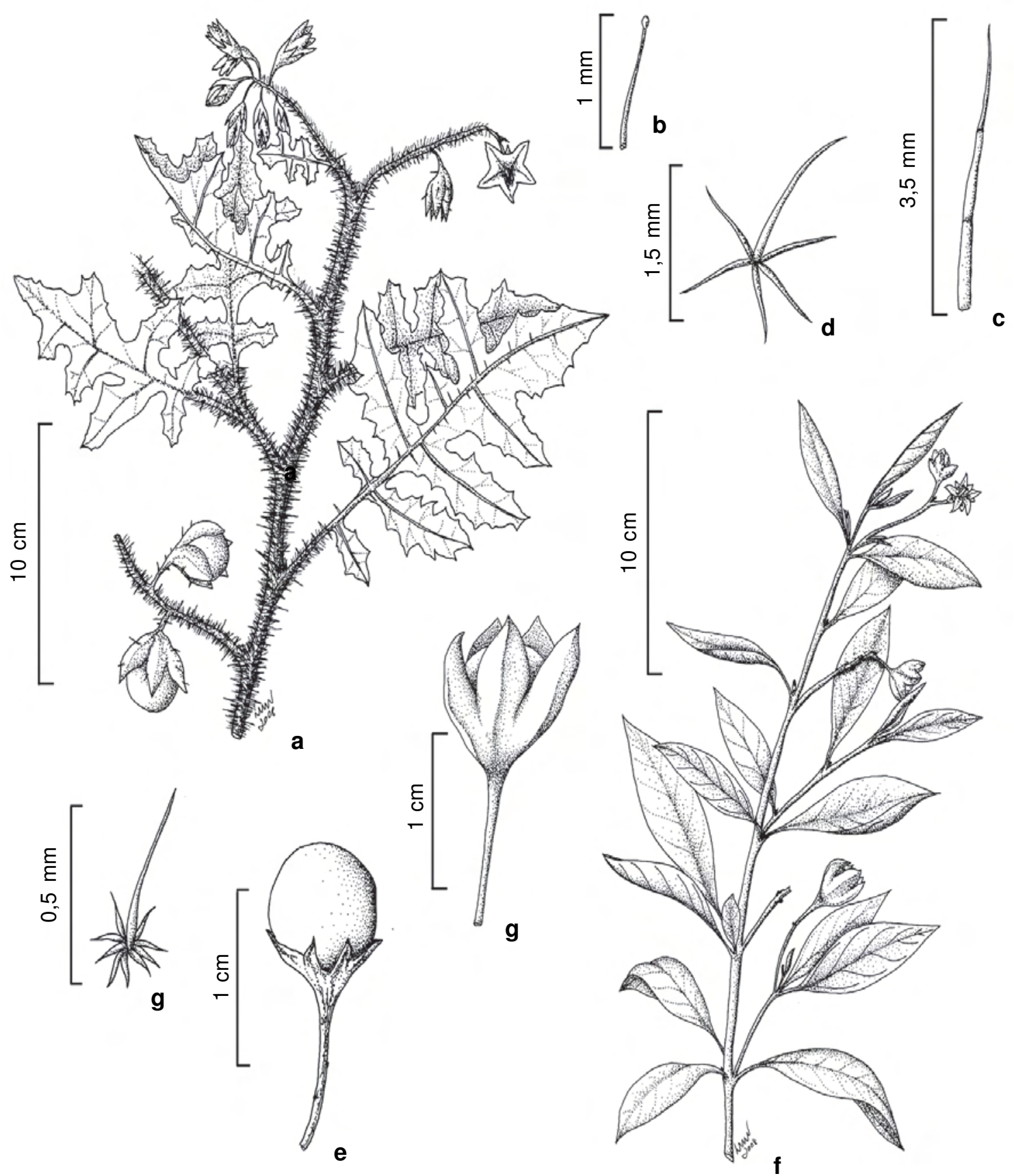

Figura 7 -a-d. Solanum sisymbriifolium -a. ramo com flores e frutos; b. tricoma glandular; c. tricoma simples; d. tricoma estrelado séssil com célula central longa e curva. e. S. subumbellatum - fruto. f-h. S. swartzianum - f. ramo com flores; g. fruto ( a-d Salimena 2366; e Menini Neto 302; f-h Salimena 2481).

Figura 7 - a-d. Solanum sisymbriifolium - a. branch with flowers and fruits, b. glandular hair; c. simple hair; d. sessile stellate hair with central long and curve cell. e. S. subumbellatum - fruit. f-h. S. swartzianum - f. branch with flowers; g. fruit (a-d Salimena 2366; e Menini Neto 302; f-h Salimena 2481). 
campanulado, lacínias triangulares; corola rotáceoestrelada, alva, 1,5-1,8 cm diâm., lacínias 5-8×2-3 mm, lanceoladas, lepidotas. Estames 5, isodínamos; filetes ca. $1 \mathrm{~mm}$ compr.; anteras amarelas, 4-5 mm compr., oblongas, deiscência poricida, prolongada por fendas longitudinais. Ovário ca. $2 \mathrm{~mm}$ diâm., ovado, tomentoso; estilete ca. $5 \mathrm{~mm}$ compr., reto, tricomas peltados, no terço basal; estigma capitado. Fruto baga, verde, 1-1,5 cm diâm., globoso, piloso; cálice acrescente, cobrindo todo o fruto.

Material examinado: Serra Negra, Região do Burro de Ouro, 26.II.2006, fl., P.L. Viana \& N.F.O. Mota 1947 (CESJ); Mata do Ninho da Égua, 28.IV.2007, fl. e fr., E.A. Feliciano et al. 44 (CESJ).

Solanum swartzianum pode ser reconhecida pela presença de tricomas peltados nos ramos, folhas, inflorescência, flores e frutos; possui também folhas com ápice acuminado a cuspidado e cálice acrescente cobrindo inteiramente o fruto. Na Serra Negra pode ser encontrada em área de transição de florestacampo e no interior e borda de matas nebulares, entre aproximadamente 900 e $1.500 \mathrm{~m}$ de altitude. É amplamente distribuída, com ocorrência na Venezuela e no Brasil, nos estados de Roraima, Amazonas, Bahia, Espírito Santo, Minas Gerais, Rio de Janeiro, São Paulo e Paraná (Carvalho 1996).

\section{Solanum vaillantii Dunal, Solan. Syn.: 38. 1816.}

Fig. 8a-c

Arbusto; ramos quadrangulares, armados, glabrescentes, raro tricomas simples, longos; acúleos aciculares. Folhas isoladas e geminadas; pecioladas; lâmina membranácea, 5,8-16,8 ×3,7$13 \mathrm{~cm}$, ovada, ápice agudo a acuminado, base truncada a assimétrica, margem lobada, com lobos longos e agudos, face adaxial verde, pilosa com tricomas simples, face abaxial verde, pilosa com tricomas estrelados, sésseis e curto pedicelados, acúleos presentes. Inflorescência escorpióide, extra-axilar. Flores pediceladas; bractéolas ausentes; cálice campanulado, lacínias triangulares; corola rotáceo-estrelada, alva, 1,4 cm compr., ca. $2,2 \mathrm{~cm}$ diâm., lacínias $10 \times 3$ mm, lanceoladas, ápice agudo, face abaxial pubescente, face adaxial glabra. Estames 5, isodínamos; filetes ca. $2 \mathrm{~mm}$ compr.; anteras amarelas, ca. $7 \mathrm{~mm}$ compr., lanceoladas, deiscência poricida, prolongada por fendas longitudinais. Ovário ca. $1 \mathrm{~mm}$ diâm., globoso, glabrescente; estilete ca. $1 \mathrm{~cm}$ compr., reto, glabro, pubérula na base; estigma capitado. Fruto baga, pêndulo, ca. 0,8-1,2 cm diâm., globoso, glabrescente; cálice não acrescente.
Material examinado: Serra Negra, Região do Burro de Ouro, 26.II.2006, fl., P.L. Viana \& N.F.O. Mota 1954 (CESJ). Material adicional examinado: ESPÍRITO SANTO: Venda Nova do Imigrante, Guaçuvirá, 31.I.1995, fl. e fr., D.A. Folli, 2535 (BHCB).

Solanum vaillantii difere das demais espécies estudadas pela presença de ramos quadrangulares com acúleos aciculares grandes, amarelados com a base negra, folhas lobadas, com lobos longos e agudos. Na Serra Negra a espécie ocorre em borda e interior de mata nebular entre 940 e $1.510 \mathrm{~m}$ de altitude. Ocorre de Minas Gerais até o Rio Grande do Sul (Whalen 1984).

26. Solanum velleum Thunb., Pl. Bras. 2: 21. 1818.

Fig. 8d-f

Arvoreta; ramos cilíndricos, armados, tomentosos com tricomas equinóides e estrelados, ramificados, curto-pedicelados, com célula central longa e curva; acúleos aciculares. Folhas isoladas; pecioladas; lâmina cartácea, 7,5-13,6×2,5-6,5 cm, elíptica, ápice agudo a acuminado, base cuneada, faces adaxial e abaxial ferrugíneas, pilosas a tomentosas com tricomas iguais aos dos ramos, acúleos presentes. Inflorescência dicotômica ramificada, terminal. Flores pediceladas; bractéolas ausentes; cálice campanulado, lacínias triangulares; corola rotáceo-pentagonal, alva, ca. 1,2 cm compr., ca. 1,4 cm diâm., lacínias ca. $8 \times 6 \mathrm{~mm}$, triangulares, ápice agudo, involuto, face abaxial tomentosa, face adaxial glabra. Estames 5, isodínamos; filetes ca. $1 \mathrm{~mm}$ compr.; anteras amarelas, ca. $5 \mathrm{~mm}$ compr., lanceoladas, deiscência poricida, prolongada por fendas longitudinais. Ovário ca. $1 \mathrm{~mm}$ diâm., globoso, piloso; estilete 4-7 mm compr., reto, pubescente, na metade basal; estigma capitado. Fruto baga, verde, rajado de alvo, ca. $1 \mathrm{~cm}$ diâm., globoso, piloso; cálice acrescente, cobrindo o terço basal do fruto.

Material examinado: Serra Negra, entre Rio PretoOlaria, Fazenda da Tiririca, fr., F.R.G. Salimena et al. 1222 (CESJ); Mata do Ninho da Égua, 9.XI.2005, fl., N.L. Abreu et al. 27 (CESJ).

Solanum velleum é característica pelo indumento ferrugíneo, corola rotáceopentagonal e estilete com tricoma glandular e dendrítico na metade basal. Na Serra Negra a espécie pode ser encontrada em afloramentos rochosos e no interior de matas nebulares, entre 1.000 e $1.510 \mathrm{~m}$ de altitude. É endêmica da Região Sudeste do Brasil (Agra 2000) e considerada rara em Minas Gerais (Oliveira-Filho 2006). 

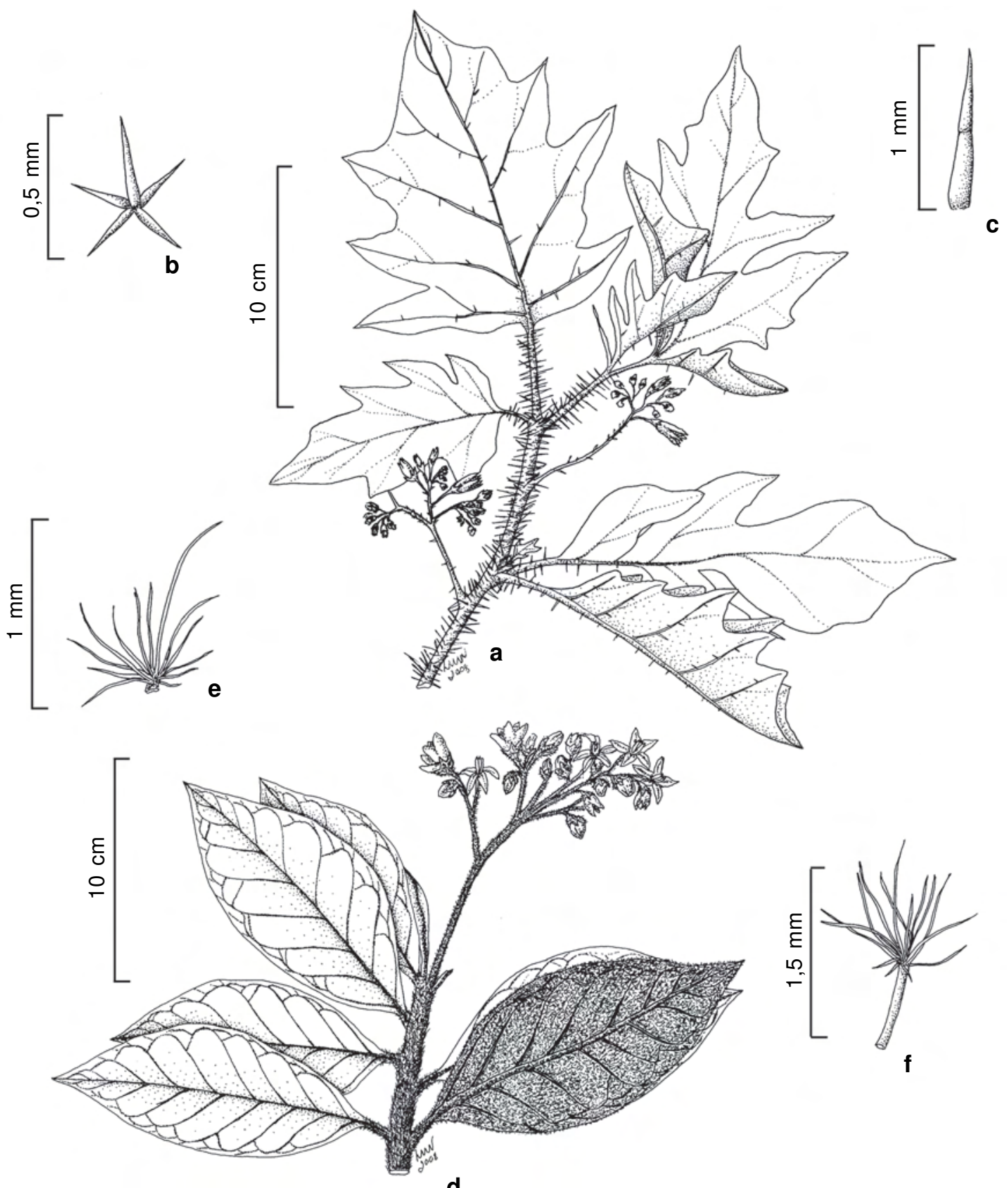

Figura 8 - a-c. Solanum vaillantii - a. ramo com inflorescências; b. tricoma estrelado séssil; c. tricoma simples; d-f. S. velleum - d.ramo com inflorescência; e. tricoma estrelado ramificado com célula central longa e curva; f. tricoma equinóide (a-c Salimena 2367; d-f Abreu 27).

Figura 8 - a-c. Solanum vaillantii - a. branch with inflorescences; b. sessile stellate hair; c. simple hair; d-f. S. velleum - d. branch with inflorescence; e. stellate hair with central long and curve cell; f. echinate hair (a-c Salimena 2367; d-f Abreu 27). 


\section{Agradecimentos}

À Fundação de Amparo à Pesquisa do Estado de Minas Gerais - FAPEMIG, o auxílio financeiro aos projetos CRA 1891/06 e CRA-APQ 1810-5.02/ 07; ao biólogo Luiz Menini Neto, as ilustrações; aos curadores dos herbários citados, o empréstimo de material.

\section{Referências}

Agra, M.F. 2000. Revisão Taxonômica de Solanum sect. Erythrotrichum Child (Solanaceae). Tese de Doutorado. Universidade de São Paulo, São Paulo. 280p.

Bohs, L. 1995. Transfer of Cyphomandra (Solanaceae) and its species to Solanum. Taxon 44: 583-587.

Bohs, L. 2001. Revision of Solanum section Cyphomandropsis (Solanaceae). Systematic Botany Monographs 61:1-85.

Carvalho, L.A.F. 1996. Espécies de Solanum das seções Cernumm Carv. \& Shep. e Lepidotum (Dun.) Seithe v. Hoff (Solanaceae). Pesquisas Botânica 46: 5-83.

Carvalho, L.A.F. 1997. Diversidade taxonômica das Solanáceas no Estado do Rio de Janeiro -Brasil: I. Albertoa 4: 245-260.

Carvalho, L.A.F. \& Bovini, M.G. 2006. Solanaceae na Reserva Rio das Pedras, Mangaratiba, Rio de Janeiro - Brasil. Rodriguésia 57: 75-98.

Carvalho, L.A.F.; Costa, H. \& Duarte, A.C. 1996. Diversidade taxonômica das Solanáceas que ocorrem no Sudeste brasileiro: listagem dos táxons. Revista Brasileira de Geografia 58: 95-109.

Costa, C. \& Herrmann, G. 2006. Plano de ação do corredor Ecológico da Mantiqueira. 1 ed. Valor Natural. 64p.

D’Arcy, W.G. 1991. The Solanaceae since 1976, with a review of its biogeography. In: J.G. Hawkes, R.N. Lester, M. Nee \& N. Estrada (eds.). Solanaceae III taxonomy, chemistry, evolution. Royal Botanic Gardens, Kew. Pp. 75-137.

Drummond, G.M.; Martins, C.S.; Machado, A.B.M.; Sebaio, F.A.; Antonini, Y. 2005. Biodiversidade em Minas Gerais: Um atlas para sua conservação. 2 ed. Fundação Biodiversitas, Belo Horizonte. 222p.

EMATER - Empresa de Assistência Técnica e Extensão Rural do Estado de Minas Gerais. 2003. Projeto APA da Serra do Funil. EMATER, Rio Preto. 63p.
Harris, J.G. \& Harris, M.W. 2003. Plant identification terminology: an illustrated glossary. Spring Lake, 2 ed. $216 \mathrm{p}$.

Hunziker, A.T. \& Barboza, G.E. 1990. Estudios sobre Solanaceae. XXX. Revision de Aureliana. Darwininana 30: 95-113.

Hunziker, A.T. 2001. Genera Solanacearum. Ruggell: A.R.G. Gantner Verlag. 500p.

Knapp, S. 2002. Solanum sect. Geminata (Solanaceae). Flora Neotropica Monograph 84: 1-405.

Menini Neto, L.; Matozinhos, C.N.; Abreu, N.L.; Valente, A.S.M.; Antunes, K. ; Souza, F.S.; Viana, P.L.; Salimena, F.R.G. 2009. Flora vascular nãoarbórea de uma floresta de grota na Serra da Mantiqueira, Zona da Mata de Minas Gerais, Brasil. Biota Neotropica 9:1-14.

Nee, M. 1999. Synopsis of Solanum in the world. In: Nee, M.; Symon, D.E.; Lester, R.N. \& Jessop, J.P. (eds.). Solanaceae IV. Royal Botanic Gardens, Kew. Pp. 285-333.

Oliveira-Filho, A.T. 2006. Catálogo das árvores nativas de Minas Gerais: mapeamento e inventário da flora nativa e dos reflorestamentos de Minas Gerais. Ed. UFLA, Lavras. 423p.

Radford, A.E.; Dickison, W.C.; Massey, J.R. \& Bell, C.R. 1974. Vascular plant systematic. Harper e Row Published, New York. 891p.

Roe, K.E. 1971. Terminology of hairs in the genus Solanum. Taxon 20: 501-508.

Smith, L.B. \& Downs, R.J. 1966. Solanáceas. Flora Ilustrada Catarinense. Vol. I. 321p.

Stehmann, J.R. \& Mentz, L.A. 2006. Riqueza e endemismo de Solanaceae na Região Sul do Brasil. In: Mariath, J.E.A. \& Santos, R.P. (orgs.). Os avanços da Botânica no início do século XXI: morfologia, fisiologia, taxonomia e genética. Sociedade Botânica do Brasil, Porto Alegre. Pp. 190-193.

Valente, A.S.M. 2007. Composição, estrutura e similaridade florística do estrato arbóreo de três fragmentos de Floresta Atlântica, na Serra Negra, município de Rio Preto, Minas Gerais, Brasil. Dissertação de Mestrado. Universidade Federal de Juiz de Fora, Juiz de Fora. 76p.

Whalen, M.D. 1984. Conspectus of species groups in Solanum subgenus Leptostemonun. Gentes Herbarum 12: 179-282. 